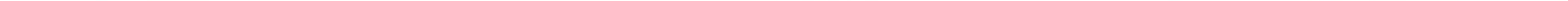




\section{DISCLAIMER}

Reference herein to any specific commercial product, process, or service by trade name, trademark, manufacturer, or otherwise, does not necessarily constitute or imply its endorsement, recommendation, or favoring by the U.S. Government or any agency thereof.

Available for sale to the public from:
U.S. Department of Commerce
National Technical Information Service
5285 Port Royal Road
Springfield, VA 22161-0002
Telephone: 800.553 .6847
Fax: 703.605.6900
E-mail: orders@ntis.gov
Online ordering: http://www.ntis.gov/ordering.htm

Available electronically at http://www.osti.gov/bridge

Available for a processing fee to the U.S. Department of Energy and its contractors, in paper, from:

U.S. Department of Energy

Office of Scientific and Technical Information

P.O. Box 62

Oak Ridge, TN 37831-0062

Telephone: 865.576 .8401

Fax: 865.576.5728

E-mail: reports@adonis.osti.gov 


\title{
National Emission Standards for Hazardous Air Pollutants Calendar Year 2006
}

\author{
By \\ Ronald W. Warren \\ and \\ Robert F. Grossman
}

June 2007

Work Performed Under

Contract No. DE-AC52-06NA25946

Prepared for:

U.S. Department of Energy

National Nuclear Security Administration

Nevada Site Office

Prepared by:

National Security Technologies, LLC

P.O. Box 98521

Las Vegas, Nevada 89193-8521 
This page intentionally left blank 


\section{EXECUTIVE SUMMARY}

\section{RADIOLOGICAL DOSE TO THE PUBLIC MEETS FEDERAL STANDARD}

The Nevada Test Site (NTS) is operated by the U.S. Department of Energy, National Nuclear Security Administration Nevada Site Office (NNSA/NSO). From 1951 through 1992, the NTS was operated as the nation's site for nuclear weapons testing. The release of man-made radionuclides from the NTS as a result of testing activities has been monitored since the first decade of atmospheric testing. After 1962, when nuclear tests were conducted only underground, the radiation exposure to the public surrounding the NTS was greatly reduced. After the 1992 moratorium on nuclear testing, radiation monitoring on the NTS focused on detecting airborne radionuclides which come from historically-contaminated soils resuspended into the air (e.g., by winds) and tritium-contaminated soil moisture emitted to the air from soils through evapotranspiration.

To protect the public from harmful levels of man-made radiation, the Clean Air Act, National Emission Standards for Hazardous Air Pollutants (NESHAP) (40 Code of Federal Regulations [CFR] 61 Subpart H) limits the release of radioactivity from a U.S. Department of Energy (DOE) facility (e.g., the NTS) to 10 millirem per year (mrem/yr) effective dose equivalent (EDE) to any member of the public. This is the dose limit established for someone living off of the NTS from radionuclides emitted to air from the NTS. This limit does not include the radiation doses that members of the public may receive through the intake of radioactive particles unrelated to NTS activities, such as those that come from naturally-occurring elements in the environment (e.g., naturally occurring radionuclides in soil or radon gas from the earth or natural building materials), or from other man-made sources (e.g., medical treatments).

The U.S. Environmental Protection Agency (EPA) requires DOE facilities to demonstrate compliance with the NESHAP dose limit by annually estimating the maximum dose to a hypothetical member of the public, referred to as the maximally exposed individual (MEI), or the member of the public who resides within an 80-kilometer (50-mile) radius of the facility and would experience the highest annual dose. This process involves air dispersion calculations and estimations of potential dose using mathematical models approved by the EPA. An alternative to air dispersion calculations for demonstrating compliance involves the use of environmental measurements of radionuclide air concentrations at critical receptor locations. This latter method was approved by EPA Region IX for demonstrating compliance for radionuclide releases from the NTS.

In 2006, as in all previous years for which this report has been produced, the estimated dose to the public from radiological emissions to air from current and past NTS activities is shown to be well below the $10 \mathrm{mrem} / \mathrm{yr}$ dose limit. Air sampling data collected onsite at each of six EPAapproved critical receptor stations on the NTS had average concentrations of nuclear test related radioactivity that were a fraction of the limits listed in Table 2 in Appendix E of 40 CFR 61. They ranged from less than 1 percent to a maximum of 25 percent of the allowed NESHAP limit. Because the nearest member of the public resides approximately 20 kilometers (12 miles) from the NTS boundary, concentrations at this location would be only a small fraction of that measured on the NTS. 


\section{DOCUMENTING NESHAP COMPLIANCE}

From 1992 through 2004, the Clean Air Package 1988 (CAP88-PC) air transport model specified in 40 CFR 61.93 was used to calculate the EDE to the MEI attributed to NTS air emissions. CAP88-PC was also used to calculate the population dose, or the collective EDE, for all individuals combined who reside within an 80-kilometer (50-mile) radius of the NTS (expressed as person-rem/yr). Since the first annual NESHAP compliance report was prepared (1992), the EDE to the MEI has consistently been less than $0.2 \mathrm{mrem} / \mathrm{yr}(0.0038$ to $0.18 \mathrm{mrem} / \mathrm{yr}$, less than 2 percent of the $10 \mathrm{mrem} / \mathrm{yr}$ limit), and the collective EDE has consistently been less than 1 person-rem/yr (0.0.029 to 0.53 person-rem/yr).

DOE Order 5400.5 specifies that dose calculations be performed using standard EPA or DOE dose conversion factors or analytical models prescribed in regulations applicable to site operations. The use of CAP88-PC and all conversion factors and mathematical methodologies used by NNSA/NSO in this report satisfied this DOE specification. In 2001 EPA Region IX approved the use of six critical receptor air sampling stations on the NTS to evaluate NESHAP compliance instead of using the estimated public dose calculated by the CAP88-PC model. The reasoning for this change is unique to the NTS and is summarized below:

1) Air sampling data reflect actual levels of re-suspended radionuclides collected continuously throughout the year and provide a more accurate and more conservative estimate of public dose. The annual dose to the MEI offsite is from diffuse NTS sources, primarily from the re-suspension of radioactively-contaminated soil from legacy sites containing americium-241 $\left({ }^{241} \mathrm{Am}\right)$, plutonium-238 $\left({ }^{238} \mathrm{Pu}\right)$, plutonium-239+240 $\left({ }^{239+240} \mathrm{Pu}\right)$, and the evaporation of tritiated water or diffusion of tritiated water vapor from ponds and soils at legacy sites and waste management sites. The six critical receptor air sampling stations can detect these emissions of airborne radionuclides at very low levels. These levels would reflect the most accurate real-time presence of re-suspended man-made radionuclides present at each station. In contrast, the CAP88-PC model was used to compute offsite dose based on annually-monitored NTS wind pattern data, a soil re-suspension mathematical model, and estimates of radionuclide concentration levels in soils based on field surveys that were conducted in the 1980s. Dose computed at each critical receptor station from the actual air sampling data will represent the highest dose possible for a member of the public if they lived at that location (on the NTS). If each station's data reflect an onsite dose of less than the $10 \mathrm{mrem} / \mathrm{yr}$ limit, this finding is more than adequate to document that the nearest member of the public residing at least 20 kilometers (12 miles) further away would experience a lower dose.

2) NTS emissions are dominated by large diffuse legacy soil sites. Measured radionuclide concentrations in air closer to these sources demonstrate compliance. Smaller releases have been shown to contribute negligible increase to the total dose to the MEI when estimated by CAP88-PC modeling. New projects and facility modifications that have a potential for airborne radioactive emissions will still be evaluated with CAP88-PC prior to and after their completion to determine compliance with NESHAP. The radiation dose to the MEl determined from these evaluations will be added to the MEI dose from legacy contamination ( $0.2 \mathrm{mrem} / \mathrm{yr}$ ) to assure that the total dose not exceed $10 \mathrm{mrem} / \mathrm{yr}$.

Data from the six critical receptor stations, along with all other air monitoring stations on the NTS, are used in this report to demonstrate compliance in lieu of computing an EDE to the MEI using the CAP88-PC air transport model. No collective population dose (in units of person$\mathrm{rem} / \mathrm{yr}$ ) to those residing within 80 kilometers (50 miles) of the NTS is reported due to the consistently low values determined from 1992 through 2004 and per approval by the DOE. 


\section{TABLE OF CONTENTS}

EXECUTIVE SUMMARY

Page

\section{iii}

LIST OF ACRONYMS AND ABBREVIATIONS.

vii

U.S. DEPARTMENT OF ENERGY, NATIONAL NUCLEAR SECURITY ADMINISTRATION, ..NEVADA SITE OFFICE AIR EMISSIONS ANNUAL REPORT (UNDER SUBPART H, TITLE 40 CODE OF FEDERAL REGULATIONS [CFR] 61.94) CALENDAR YEAR (CY) 2006

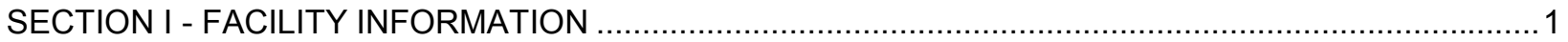

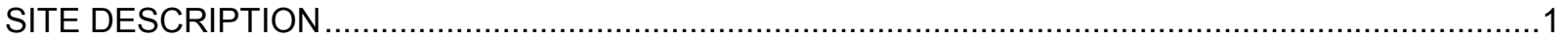

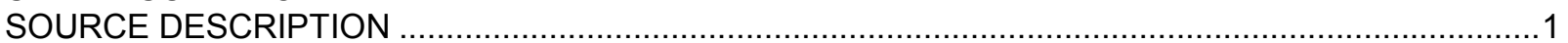

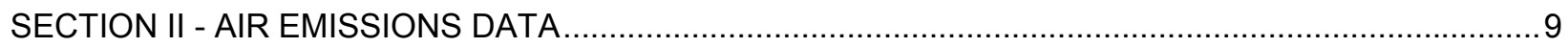

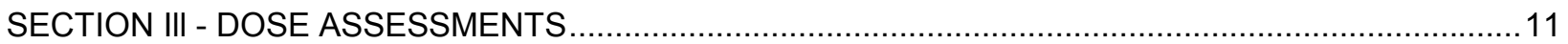

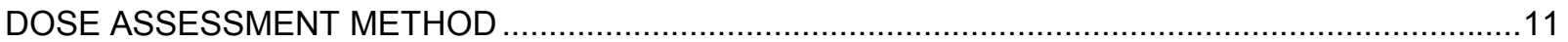

COMPLIANCE ASSESSMENT

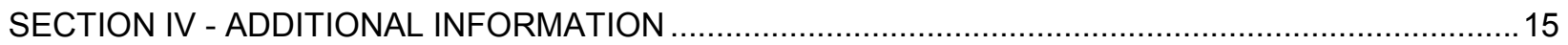

NEW CONSTRUCTION/MODIFICATION ACTIVITIES AT THE NTS …......................................15

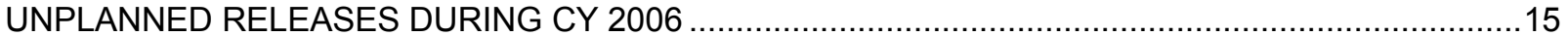

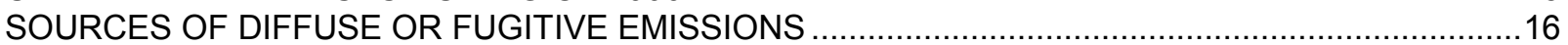

CERTIFICATION

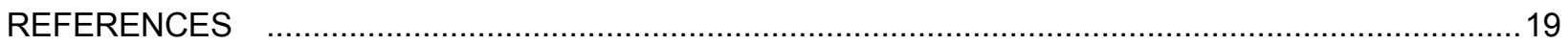

APPENDICES

APPENDIX A - PUBLIC DOSE CALCULATIONS FOR THE RELEASE OF TRITIUM FROM THE A-1 BUILDING, NLVF ............................................................... A-1

APPENDIX B - CALCULATION OF TRITIUM EMISSIONS FROM NTS PONDS …............................... B-1

APPENDIX C - POTENTIAL RADIONUCLIDE EMISSIONS FROM RADIO-

ANALYTICAL LABORATORIES

C-1

APPENDIX D - TRITIUM EMISSIONS ESTIMATED FROM AIR SAMPLING DATA …........................ D-1

APPENDIX E - EMISSIONS OF AMERICIUM AND PLUTONIUM FROM LEGACY

SITES BASED ON HISTORIC SOIL SURVEY DATA AND SOIL RE-SUSPENSION MODEL

APPENDIX F - RADIONUCLIDE EMISSIONS FROM ENVIRONMENTAL

RESTORATION, RESEARCH, OR CONSTRUCTION PROJECTS

APPENDIX G - IDENTIFICATION AND JUSTIFICATION FOR THE DEVELOPMENT

OF METEOROLOGICAL DATA USED AS INPUT TO CLEAN AIR PACKAGE 1988

(CAP88-PC)

APPENDIX H - SUPPLEMENTAL INFORMATION.

DISTRIBUTION LIST.

$\mathrm{DL}-1$ 


\section{LIST OF FIGURES}

$\underline{\text { Page }}$

Figure 1.0 Map of the NTS and Surrounding Populated Areas .......................................... 2

Figure 2.0 Sources of Radioactive Contamination and Air Sampling Network on the NTS ......... 3

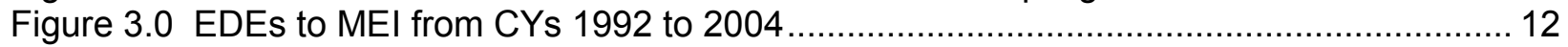

Figure 4.0 Schooner Air Sampling Compliance Station ................................................ 14

Figure F.1 Potential Dose from Research Project(s) in 2006 .........................................F-2

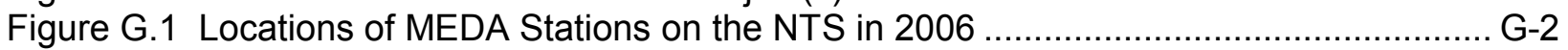

Figure H.1 CEDE to Populations within 80 km (50 mi) of Emission Sources........................ H-1

Figure H.2 CAP88 Predicted Air Concentration versus Ratio of

Distance-to-Source/Diameter of Source

\section{LIST OF TABLES}

$\underline{\text { Page }}$

Table 1.0 Inventory of ${ }^{241} \mathrm{Am},{ }^{238} \mathrm{Pu}$, and ${ }^{239+240} \mathrm{Pu}$ in Surface Soil at the NTS ......................... 6

Table 2.0 Summary of Annual Air Emissions Data by Source ........................................... 9

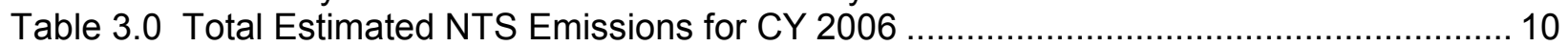

Table 4.0 Measured Radionuclide Concentrations at NTS Compliance Sampling Stations ..... 13

Table A.1 Comparison of Tritium Emission Rates from 1995-2006.......................................A-1

Table B.1 Tritium Concentrations and Water Volumes used to Estimate Tritium Emissions From NTS ponds.

Table D.1 Tritium Emissions from Airborne Tritium Sampling Results during 2006D-2

Table E.1 Calculated Emissions from Inventories of Plutonium and Americium in NTS Areas

Table F.1 Research Project Total Activity Released to Air $\mathrm{F}-1$ 


\section{LIST OF ACRONYMS AND ABBREVIATIONS}

\begin{tabular}{|c|c|}
\hline Am & americium \\
\hline ARL/SORD & Air Resources Laboratory, Special Operations and Research Division \\
\hline & Bechtel Nevada \\
\hline CAP88-PC & Clean Air Package 1988 (EPA software program for estimating doses) \\
\hline CFR & Code of Federal Regulations \\
\hline $\mathrm{Ci}$ & curie(s) \\
\hline $\mathrm{cm}$ & centimeter(s) \\
\hline $\mathrm{cm}^{2}$ & square centimeters \\
\hline $\mathrm{cm} / \mathrm{yr}$ & centimeter(s)/year \\
\hline Cs & cesium \\
\hline CY & calendar year \\
\hline DAF & Device Assembly Facility \\
\hline DPF & Dense Plasma Focus \\
\hline DoD & U.S. Department of Defense \\
\hline DOE & U.S. Department of Energy \\
\hline DRA & Desert Rock Meteorological Observatory \\
\hline EDE & effective dose equivalent \\
\hline EPA & U.S. Environmental Protection Agency \\
\hline ERDA & Energy Research and Development Administration \\
\hline $\mathrm{F}$ & Fahrenheit \\
\hline FFACO & Federal Facility Agreement and Consent Order \\
\hline & foot or (feet) \\
\hline $\mathrm{ft}^{3} / \mathrm{min}$ & cubic feet per minute \\
\hline GBq & gigabecquerel \\
\hline${ }^{3} \mathrm{H}$ & tritium \\
\hline HEPA & high-efficiency particulate air \\
\hline HTO & tritiated water \\
\hline in/yr & inch(es)/year \\
\hline I & iodine \\
\hline JASPER & Joint Actinide Shock Physics Experimental Research \\
\hline $\mathrm{kCi}$ & kilocurie(s) $(1 \mathrm{kCi}=1,000 \mathrm{Ci})$ \\
\hline $\mathrm{kg} / \mathrm{m}^{2}$ & kilogram(s) per square meter \\
\hline $\mathrm{km}$ & kilometer(s) \\
\hline $\mathrm{km}^{2}$ & square kilometers \\
\hline $\mathrm{km} / \mathrm{hr}$ & kilometer(s) per hour \\
\hline $\mathrm{Kr}$ & krypton \\
\hline L & liter(s) \\
\hline LLW & low-level waste \\
\hline $\mathrm{m}$ & meter(s) \\
\hline $\mathrm{m}^{3}$ & cubic meters \\
\hline $\mathrm{mCi}$ & millicurie(s) \\
\hline MDC & minimum detectable concentration \\
\hline MEDA & Meteorological Data Acquisition System \\
\hline MEI & maximally exposed individual \\
\hline $\mathrm{mi}$ & mile(s) \\
\hline $\mathrm{mi}^{2}$ & square mile(s) \\
\hline MIDNET & Meteorological Integrated Data Network \\
\hline mph & mile(s) per hour \\
\hline $\begin{array}{l}\text { mrem } \\
\text { mrem/yr }\end{array}$ & $\begin{array}{l}\text { millirem or milli-roentgen equivalent man }\left(1 \mathrm{mrem}=0.001\left(1 \times 10^{-3}\right) \text { rem }\right. \\
\text { millirem per year }\end{array}$ \\
\hline
\end{tabular}




\section{LIST OF ACRONYMS AND ABBREVIATIONS (continued)}

$\begin{array}{ll}\text { NESHAP } & \text { National Emission Standards for Hazardous Air Pollutants } \\ \text { NLVF } & \text { North Las Vegas Facility } \\ \text { NNSA/NSO } & \text { U.S. Department of Energy, National Nuclear Security Administration Nevada } \\ & \text { Site Office } \\ \text { NOAA } & \text { National Oceanic and Atmospheric Administration } \\ \text { NRC } & \text { U.S. Nuclear Regulatory Commission } \\ \text { NTS } & \text { Nevada Test Site } \\ \text { NTTR } & \text { Nevada Test and Training Range } \\ \text { pCi/L } & \text { picocurie(s) per liter } \\ \text { pCi/m } & \text { picocurie(s) per cubic meter } \\ \text { Pu } & \text { plutonium } \\ \text { rem } & \text { roentgen equivalent man } \\ \text { rem/yr } & \text { rem per year } \\ \text { Rn } & \text { radon } \\ \text { RWMS } & \text { Radioactive Waste Management Site } \\ \text { S } & \text { second(s) } \\ \text { SNM } & \text { special nuclear materials } \\ \text { Sr } & \text { strontium } \\ \text { STAR } & \text { Stability Array (grouping of meteorological data) } \\ \text { Th } & \text { thorium } \\ \text { TRU } & \text { transuranic (nuclides with atomic numbers greater than uranium) } \\ \text { TTR } & \text { Tonopah Test Range } \\ \text { U } & \text { uranium } \\ \text { UCC } & \text { Yucca Flat Meteorological Observatory } \\ \mu C i & \text { microcurie (1 } \mu \text { Ci = 0.000001 (1 x 10-6) Ci) } \\ \mu R / h r & \text { microroentgen per hour } \\ \mu r e m / y r & \text { microroentgen equivalent man per year } \\ \text { Xe } & \text { xenon } \\ \text { yr } & \text { year(s) } \\ & \end{array}$




\section{U.S. Department of Energy \\ National Nuclear Security Administration \\ Nevada Site Office \\ Air Emissions Annual Report \\ (under Subpart H, Title 40 Code of Federal Regulations [CFR] 61.94) \\ Calendar Year (CY) 2006}

Site Name: $\quad \underline{\text { Nevada Test Site }}$

\section{Office Information}

Office: $\quad$ U.S. Department of Energy, National Nuclear Security Administration Nevada Site Office

Address: $\quad$ P.O. Box 98518

Las Vegas, NV 89193-8518

Contact: $\quad$ W. Don Seaborg $\quad$ Phone: (702) 295-4752

Assistant Manger for Safety Programs

\section{Site Information}

January 1 - June 30, 2006

Operator: Bechtel Nevada

Address: $\quad$ P.O. Box 98521

Las Vegas, NV 89193-8521

Contact: Wayne F. Johnson Phone: (702) 295-0473

$\underline{\text { Assistant General Manager, Environmental Management }}$

July 1 - December 31, 2006

Operator: National Security Technologies, LLC

Address: $\quad$ P.O. Box 98521

Las Vegas, NV 89193-8521

Contact: $\quad$ John Ciucci $\quad$ Phone: (702) 295-0473

Director, Environmental Management 
This page intentionally left blank 


\section{SECTION I FACILITY INFORMATION}

\section{SITE DESCRIPTION}

The Nevada Test Site (NTS) is operated by the U.S. Department of Energy (DOE), National Nuclear Security Administration Nevada Site Office (NNSA/NSO) as the site for experiments in support of the national Stockpile Stewardship Program and the activities listed below. Located in Nye County, Nevada, the site's southeast corner is about 105 kilometers (km) (65 miles [mi]) northwest of the major population center, Las Vegas, Nevada. The NTS covers about $3,561 \mathrm{~km}^{2}$ $\left(1,375 \mathrm{mi}^{2}\right)$, an area larger than Rhode Island. Its size is 46 to $56 \mathrm{~km}$ (28 to $35 \mathrm{mi}$ ) east to west and from 64 to $88 \mathrm{~km}$ (40 to $55 \mathrm{mi})$ north to south. The NTS is surrounded, except on the south side, by public exclusion areas (Nevada Test and Training Range [NTTR]) that provide another 24 to $104 \mathrm{~km}$ (15 to $65 \mathrm{mi}$ ) between the NTS and public lands (Figure 1.0). The NTS is characterized by desert valley and Great Basin mountain topography, with a climate, flora, and fauna typical of the southwest deserts. Population density within $80 \mathrm{~km}(50 \mathrm{mi})$ from the NTS boundary is about 1.0 persons $/ \mathrm{km}^{2}\left(2.6\right.$ person $\left./ \mathrm{mi}^{2}\right)$. Restricted access, low population density in the surrounding area, and extended wind transport times are advantageous factors for the activities conducted at the NTS. Surface waters are scarce on the NTS, and slow-moving groundwater is present hundreds to thousands of feet below the land surface.

\section{SOURCE DESCRIPTION}

The sources of radionuclides include current and previous activities conducted on the NTS (Figure 2.0). The NTS was the primary location for testing of nuclear explosives in the Continental U.S. between 1951 and 1992. Historical testing has included (1) atmospheric testing in the 1950s and early 1960s, (2) underground testing between 1951 and 1992, and (3) open-air nuclear reactor and rocket engine testing (DOE, 1996a). No nuclear tests have been conducted since September 23,1992 (DOE, 2000). Radionuclides remaining on the soil surface in some NTS areas after several decades of radioactive decay have the potential to become re-suspended into the atmosphere at concentrations that can be detected by onsite air sampling stations. This report and those produced since 1992, have shown that these airborne radionuclides are well within the limit established by the Clean Air Act, National Emission Standards for Hazardous Air Pollutants (NESHAP) of 10 millirem per year (10 mrem/yr) from NTS sources. (In comparison, a crosscountry commercial airline flight at 30,000 feet [ft] would result in a dose of $5 \mathrm{mrem} / \mathrm{yr}$ from direct exposure to cosmic rays.)

Limited non-nuclear testing includes spills of hazardous materials at the Non-Proliferation Test and Evaluation Complex, private technology development, demilitarization activities, and site remediation activities.

Programs and activities involving radioactive materials include laboratory analyses; handling, transport, storage, and assembly of radioactive targets for the Joint Actinide Shock Physics Experimental Research (JASPER) gas gun; conducting subcritical experiments at U-1a; and operation of radioactive waste management sites (RWMSs) for low-level radioactive and mixed waste (DOE, 1996a). Monitoring and evaluation of the various activities conducted onsite indicate that the potential sources of offsite radiation exposure in calendar year (CY) 2006 were releases from (1) diffuse sources of tritium $\left({ }^{3} \mathrm{H}\right)$ and re-suspension of plutonium $\left({ }^{239+240} \mathrm{Pu}\right)$ and americium $\left({ }^{241} \mathrm{Am}\right)$ at the sites of past nuclear tests; (2) evaporation of tritiated water (HTO) from ponds, such as the $E$ Tunnel ponds in Area 12 and a sewage lagoon in Area 5 in which water containing low concentrations of tritium from Building A-1 at the North Las Vegas Facility (NLVF) was disposed; 


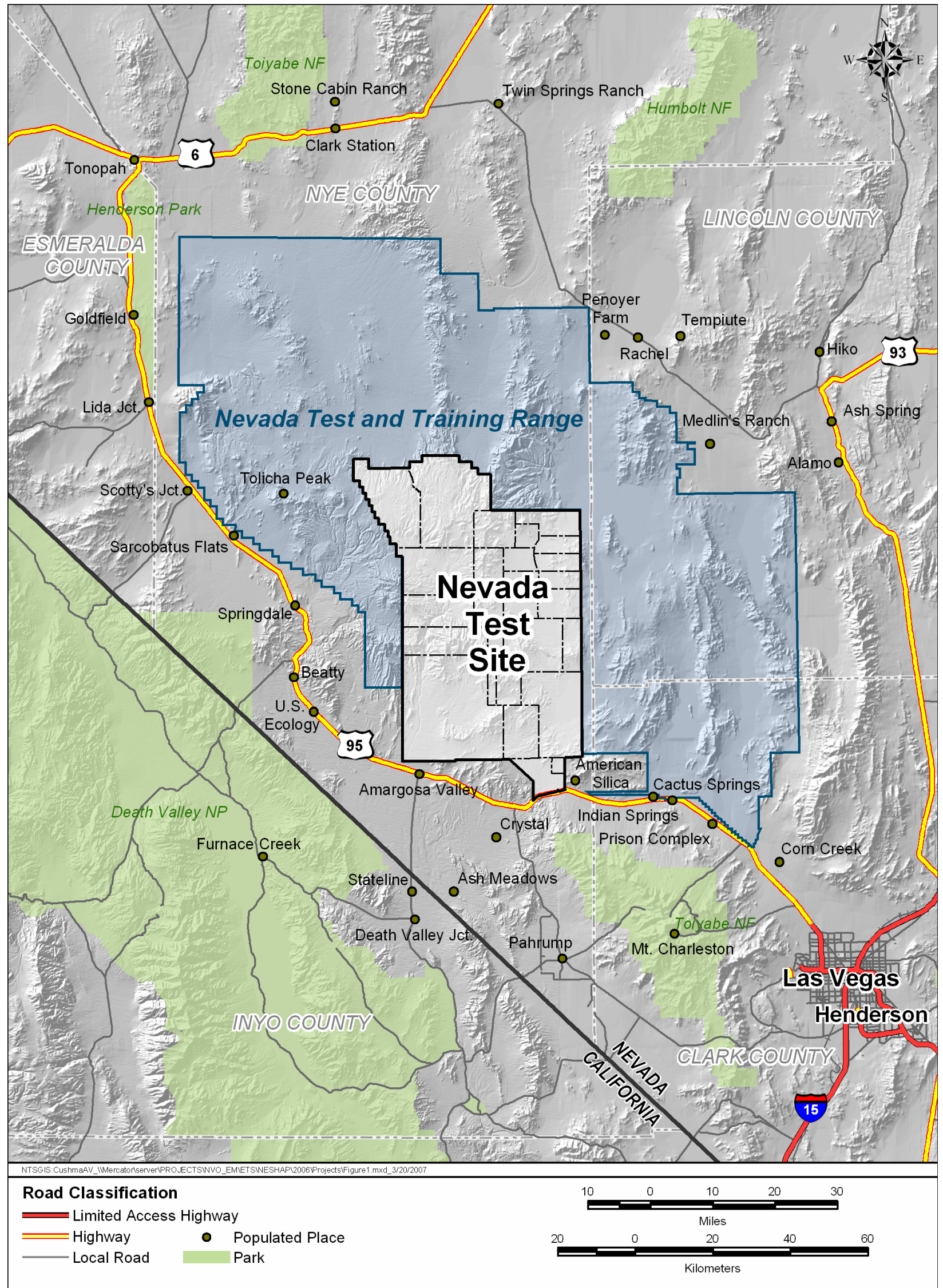

Figure 1.0 Map of the NTS and Surrounding Populated Areas 


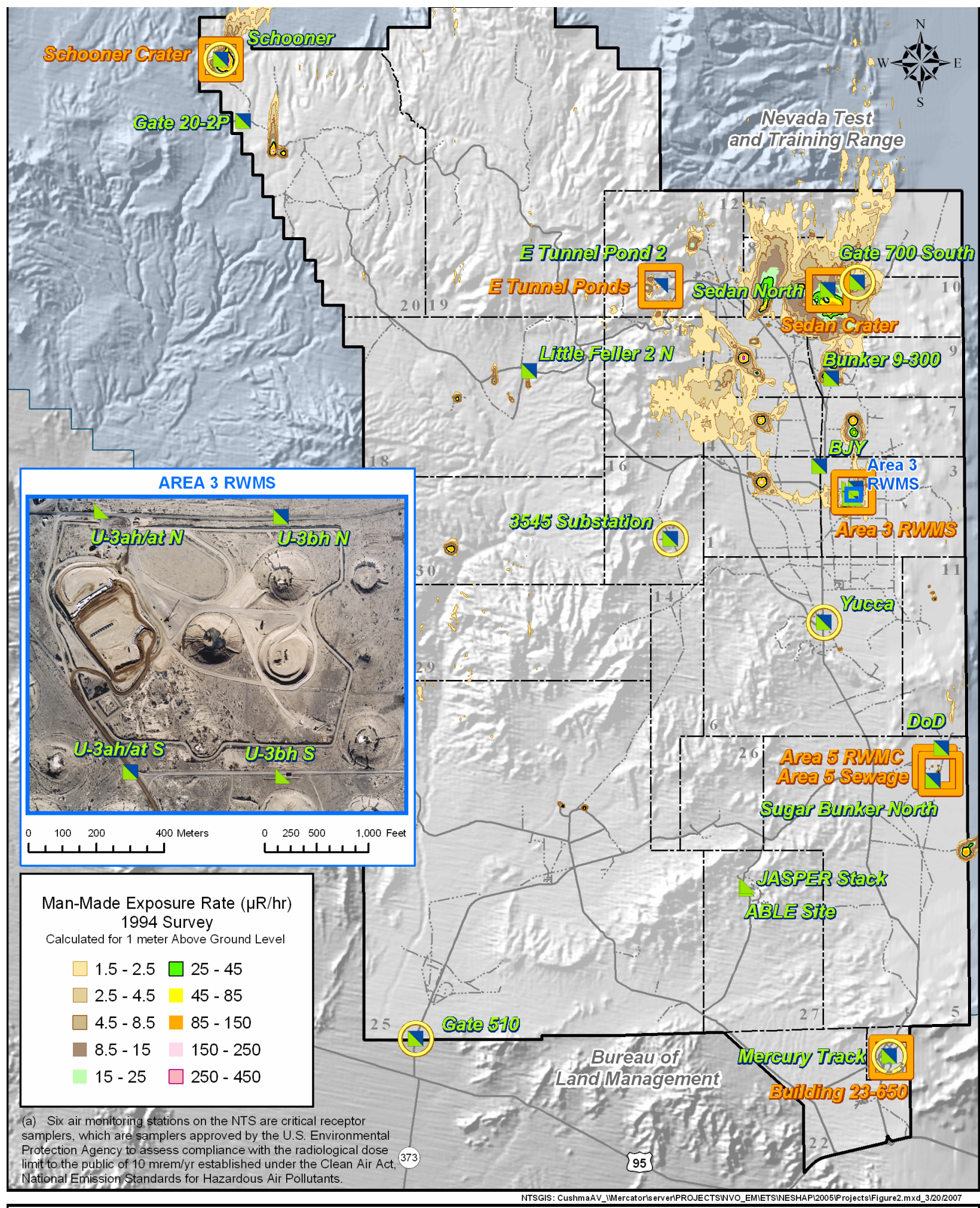

Air Sampling Network

Air Particulate (AP) Station

$\checkmark$ Tritium (HTO) Station

Critical Receptor Sampler ${ }^{(a)}$

NTS Operational Areas

- AP and HTO Station

Sources of Tritium Emissions

Wilometers

\begin{tabular}{lrrrrr}
2 & 1 & 0 & 2 & 4 & 6 \\
\hline
\end{tabular}

Figure 2.0 Sources of Radioactive Contamination and Air Sampling Network on the NTS 
(3) the Area 3 and Area 5 RWMS facilities; and (4) onsite radioanalytical laboratories. It is improbable that radioactive emissions would be released into the atmosphere during the preparation and performance of subcritical experiments at $U-1 a$. The following sections present a general description of the present emission sources on the NTS and at the NLVF.

\section{North Las Vegas Facility}

At the NLVF, parts of the Building A-1 basement were contaminated with tritium by a previous contractor in 1995. The incident involved the release of tritium as HTO. This unusual occurrence led to a very small potential exposure $(<0.001 \mathrm{mrem} / \mathrm{yr})$ to an offsite person. The HTO emission has continued at lower levels (probably re-emanation from building materials), even after cleanup activities in November and December 1997. A description of the incident and the potential effective dose equivalent (EDE) for offsite exposure during CY 2006 are presented in Appendix A.

\section{Tunnel Operations}

Nuclear explosive tests have been conducted within tunnel complexes mined into the Rainier Mesa region (Area 12) and in Areas 15 and 16. When these tests were conducted, purging gases from the tunnels occasionally resulted in releases of radioactivity, and contaminated water drained from the tunnels into containment ponds (Energy Research and Development Administration [ERDA], 1977). No nuclear testing activities have occurred since 1992.

\section{Ponds}

Water contaminated with radionuclides seeped from the tunnels in Area 12 and was collected in ponds resulting in water evaporation and seepage into the soil. The tunnels have been sealed, but water continues to seep from E Tunnel. The only radiological contaminant which produces a measurable air emission from evaporation of the water is tritium (as HTO). Calculation of the source term for this emission is described in Appendix B.

To characterize the groundwater regime under the NTS, suitable wells are being drilled and existing wells re-completed in the vicinity of certain underground tests and at other locations on the NTS, as determined by hydrologists. During these drilling operations, if the tritium level exceeds $4 \times 10^{5}$ picocuries per liter ( $\mathrm{pCi} / \mathrm{L}$ ), contaminated water is pumped from the wells and diverted to lined containment ponds, as required by the State and explained in the Underground Test Area Program Waste Management Plan (DOE, 2002). During CY 2006, no water containing tritium above background levels was pumped.

In the basement of Building A-1 in the NLVF, a vacant radiation source well used in the past for calibrating radiation instruments has been filling with water due to the soil bottom in the well and a rise in the ground water level. Concentrations of tritium found in the water from this source well were attributed to the tritium contaminating incident at the NLVF in 1995. A representative of the state of Nevada was informed of the problem and approved the disposal of the water by evaporation with evaporative coolers outside the north side of Building A-1 and by disposal in the Area 5 Sewage Lagoon at the NTS when the evaporative coolers were not effective. The tritium emissions from the evaporative coolers and the Area 5 Sewage Lagoon are estimated in Appendices $A$ and $B$, respectively.

\section{Laboratories}

Radiological analyses were conducted in laboratories located in Area 23 Buildings 650 and 652 (in Mercury), Building CP-95A (in Area 6), and the Device Assembly Facility (DAF) (in Area 6). Because these facilities process environmental samples, very little radioactivity passes through 
them. However, there is potential for some radionuclides to be discharged into the atmosphere from the hood ventilation systems during sample processing, particularly of spiked samples, or from loss of radioactive standards in liquid or gaseous form.

This year, the only laboratory emission was tritium gas which was used by laboratory personnel at Area 23 Building 650 while calibrating analytical equipment. The tritium emission from this source is described in Appendix $\mathrm{C}$.

Non-volatile radioactive standards and sealed radiation sources were controlled in accordance with Title 10 Code of Federal Regulations (CFR) 835.

\section{Radioactive Waste Management Sites}

The Area 3 RWMS and the Area 5 RWMS are used for the disposal of low-level wastes (LLW). Disposal is accomplished by the use of pits and trenches. The Area 5 RWMS is also used for accumulation of mixed waste and storage of transuranic (TRU) and mixed TRU wastes. Concrete pads are used for temporary storage of wastes. At the Area 5 RWMS, only packaged, dry wastes are accepted for disposal. The facility is considered a diffuse source of radiological effluents. The only radioactive emission detected by the various types of samplers located downwind of the site and attributed to site operations was tritium as HTO in atmospheric moisture. The calculation of the tritium source term for these emissions is explained in Appendix D. Since the Area 3 RWMS LLW site is in a location where the surrounding surface soil has been contaminated by past nuclear tests, the re-suspension of this soil by wind or vehicular activity results in above-background levels of plutonium being detected in air samples collected outside the perimeter fence. Due to past disposal of waste containing tritium at the Area 3 RWMS, air samplers for tritium were installed at the northeast and southwest corners of the perimeter fence on November 8, 2004. The calculation of the tritium source term for these emissions is also explained in Appendix D.

\section{JASPER}

Approval by the U.S. Environmental Protection Agency (EPA) was obtained in June 1999 for the construction of a hydrogen gas gun in Building 5100 in Area 27 using special nuclear material and other actinide materials as targets. To assure that the emissions are in conformance with NESHAP, a stack monitoring system was installed downstream of high efficiency particulate air (HEPA) filters. In June 2000, the construction and startup phase was completed. Beginning in June 2003, equation-of-state experiments, with the two-stage light gas gun, were begun using plutonium as target material. From the results of the stack monitoring system, no radioactive emissions from the experiments conducted during CY 2006 were detected.

\section{Surface Areas Contaminated with Tritium, Plutonium, or Americium}

Tritium emanation from the cratering tests Sedan and Schooner was detectable in atmospheric moisture samples collected on molecular sieves by special air samplers. Derivation of the tritium emissions for these locations is described in Appendix D. 
Surface soils in some areas on the NTS were contaminated with plutonium and/or tritium from either nuclear device safety, atmospheric, or cratering tests, using nuclear explosives. An investigation of these areas during the Nevada Applied Ecology Group studies, updated by the Desert Research Institute (DOE, 1991), developed an inventory of radionuclides (Table 1.0). The inventory is an estimate of the curies (Ci) of each radionuclide in surface soil (within 0-30 centimeters [cm] of the surface, most activity in the top $5 \mathrm{~cm}$ ) within each study area.

Table 1.0 Inventory of ${ }^{241} \mathrm{Am},{ }^{238} \mathrm{Pu}$, and ${ }^{239+240} \mathrm{Pu}$ in Surface Soil ${ }^{(\mathrm{a})}$ at the NTS

\begin{tabular}{|c|c|c|c|c|}
\hline \multirow{2}{*}{$\begin{array}{c}\text { NTS } \\
\text { Administrative } \\
\text { Area Studied }\end{array}$} & \multirow{2}{*}{$\begin{array}{l}\text { Study Site Area in } \mathrm{mi}^{2} \text { I } \\
\text { Percent of Total } \\
\text { Administrative Area }\end{array}$} & \multicolumn{3}{|c|}{ Radionuclide Inventory (Ci) } \\
\hline & & ${ }^{241} \mathrm{Am}$ & ${ }^{238} \mathrm{Pu}$ & ${ }^{239+240} \mathrm{Pu}$ \\
\hline 1 & $26.5 / 100$ & 4.2 & 6.5 & $24^{(\mathrm{b})}$ \\
\hline 2 & $19.7 / 100$ & 2.9 & 8.6 & $22^{(\mathrm{b})}$ \\
\hline 3 & $32.3 / 100$ & 4.6 & 3.1 & 37 \\
\hline 4 & $16.0 / 100$ & 6.6 & 13 & $40^{(\mathrm{b})}$ \\
\hline 5 & $2.9 / 3$ & 0.6 & 0.1 & $4.8^{(\mathrm{b})}$ \\
\hline 6 & $32.3 / 81$ & 1.7 & 3.3 & $8.4^{(\mathrm{b})}$ \\
\hline 7 & $19.3 / 100$ & 2.2 & 0.6 & $16^{(\mathrm{b})}$ \\
\hline 8 & $13.9 / 100$ & 17 & 8.0 & 110 \\
\hline 9 & $20.0 / 98$ & 4.2 & 2.2 & 89 \\
\hline 10 & $20.0 / 99$ & 19 & 19 & 110 \\
\hline 11 & $4.0 / 16$ & 3.3 & 0.5 & 29 \\
\hline 12 & $39.6 / 100$ & 5.7 & 8.5 & $39^{(\mathrm{b})}$ \\
\hline 15 & $35.3 / 100$ & 8.0 & 7.8 & $63^{(\mathrm{b})}$ \\
\hline 16 & $14.3 / 50$ & 0.7 & 1.5 & $3.7^{(\mathrm{b})}$ \\
\hline 17 & $31.4 / 100$ & 2.8 & 4.5 & $18^{(b)}$ \\
\hline 18 & $27.3 / 31$ & 19 & 5.6 & 100 \\
\hline 19 & $148.3 / 100$ & 21 & 32 & $140^{(b)}$ \\
\hline 20 & $6.2 / 6$ & 23 & 30 & 41 \\
\hline 25 & $0.9 / 0.004$ & 0 & 0 & 0 \\
\hline 26 & $0.2 / 0.009$ & 0 & 0 & 0 \\
\hline 30 & $0.3 / 0.0051$ & 3.2 & 4.5 & $14^{(\mathrm{b})}$ \\
\hline
\end{tabular}

Source: (DOE, 1991)

(a) Soil within $0-30 \mathrm{~cm}$ of the surface with most activity in the top $5 \mathrm{~cm}$.

(b) DOE, 1991 indicated that these levels were probably the result of historical fallout from nuclear tests in surrounding areas.

These contaminated areas on the NTS could become sources of radionuclide exposure to the public if the soils were to be re-suspended, e.g., during windy conditions, surface cleanup, construction, vehicular travel, or similar activities. Figure 2.0 shows the approximate locations of the contaminated areas based upon an aerial survey conducted in 1994 . These areas are considered diffuse sources of radioactive emissions. The derivation of the radioactive emissions for these NTS contaminated areas is explained in Appendix E. 


\section{Environmental Restoration Projects}

Under the Federal Facility Agreement and Consent Order (FFACO) between the DOE, the U.S. Department of Defense, and the state of Nevada (FFACO, 1996), radioactive soil contamination generated by historical NTS activities is being addressed. Two surface areas northwest of the NTS on the NTTR including the Tonopah Test Range have had partial source removal, resulting in a decrease in the offsite EDE. These surface areas are DOUBLE TRACKS, remediated in 1996, and CLEAN SLATE I in 1997. The monitoring plan for such activities required continuous air sampling before, during, and after cleanup operations until the concentration in air returned to background levels. During 2006, no further remediation work or air monitoring was conducted in these areas.

Environmental restoration projects that involved the removal and haulage of materials and soil containing low concentrations of radioactivity were evaluated for potential radionuclide emissions to air and potential dose offsite. These are performed in accordance with 40 CFR 61, Subpart $\mathrm{H}$ requirements. Summaries of evaluations performed in 2006 can be found in Appendix $F$. The results of these evaluations showed radioactive emissions of less than $1 \mu \mathrm{Ci}$, many orders of magnitude less than the quantity of radioactivity that would result in an offsite dose of 0.1 $\mathrm{mrem} / \mathrm{yr}$. Only emissions for radionuclides producing the majority of the dose, ${ }^{239+240} \mathrm{Pu}$ and

${ }^{241} \mathrm{Am}$ in particular, were included in the Source Type category, "Miscellaneous Projects" shown in Table 2.0.

\section{Research and Construction Projects}

Multiple research projects are conducted on the NTS which involve the use of radioactive sources. The vast majority of these use sealed sources and no emissions are produced. In September 2006 a multi-organization research project was conducted in which a release of low quantities of uranium isotopes resulted. Assessment of the potential dose from this release is described in Appendix F.

A construction project was planned for Area 8 on the NTS which was to involve the movement of soil for the purpose of flood control and sediment transport mitigation. Only a fraction of a microcurie of ${ }^{239+240} \mathrm{Pu}$ was estimated to be the emission potential for this project. Assessment of the potential dose from this release is described in Appendix $\mathrm{F}$ also. 
This page intentionally left blank 


\section{SECTION II AIR EMISSIONS DATA}

Each potential source of NTS emissions was characterized by one of the following methods: (1) monitoring methods using procedures previously developed at the NTS; (2) measuring radionuclide inventory in laboratories, identifying losses of radionuclides that were released to the environment; (3) measuring tritiated water concentrations in liquid effluents discharged to containment ponds and assuming all the effluent evaporates over the course of the year to become an air emission; (4) using re-suspension calculations; and (5) using a combination of environmental measurements and the Clean Air Package 1988 (CAP88-PC) air dispersion model (EPA, 2006) to calculate the emissions. According to Title 40 CFR 61.93 (b)(4)(ii) (CFR, 2002), no credit was taken for pollution control equipment in determining air emissions. The emissions for NESHAP reporting are listed in Table 2.0. These emissions are conservative (worst-case). Appendices $\mathrm{A}$ through $\mathrm{F}$ describe the methods used to determine the emissions from the sources listed in Table 2.0.

Table 2.0 Summary of Annual Air Emissions Data by Source ${ }^{(a)}$ (Multiply Ci by 37 to obtain gigabecquerels [GBq])

\begin{tabular}{|c|c|c|c|c|}
\hline Source Type & $\begin{array}{c}\text { Type of } \\
\text { Emissions } \\
\text { Control }\end{array}$ & $\begin{array}{l}\text { Distance to } \\
\text { Nearest Member of } \\
\text { the Public }\end{array}$ & Nuclide & $\begin{array}{l}\text { Annual } \\
\text { Quantity } \\
\text { (Ci) }\end{array}$ \\
\hline \multicolumn{5}{|l|}{ Point Sources } \\
\hline Building 650, Area 23 & None & $5.5 \mathrm{~km}(3.4 \mathrm{mi})$ & ${ }^{3} \mathrm{H}$ & 0.0000225 \\
\hline Building A-1, NLVF (a) & None & $0.1 \mathrm{~km}(328 \mathrm{ft})$ & ${ }^{3} \mathrm{H}$ & 0.012 \\
\hline Miscellaneous Projects & None & $35 \mathrm{~km}(21.7 \mathrm{mi})$ & ${ }^{234} \mathrm{U}$ & 0.000108 \\
\hline Miscellaneous Projects & None & $35 \mathrm{~km}(21.7 \mathrm{mi})$ & ${ }^{235} \mathrm{U}$ & 0.000004 \\
\hline Miscellaneous Projects & None & $35 \mathrm{~km}(21.7 \mathrm{mi})$ & ${ }^{236} U$ & 0.000001 \\
\hline Miscellaneous Projects & None & $35 \mathrm{~km}(21.7 \mathrm{mi})$ & ${ }^{238} \mathrm{U}$ & 0.000002 \\
\hline $\begin{array}{l}\text { Miscellaneous Projects } \\
\text { Area Sources }\end{array}$ & None & 50 km (31 mi) & ${ }^{239+240} \mathrm{Pu}$ & 0.0000006 \\
\hline E Tunnel Ponds & None & $50 \mathrm{~km}(31 \mathrm{mi})$ & ${ }^{3} \mathrm{H}^{(\mathrm{b})}$ & 9.8 \\
\hline RWMS-3 & None & 47 km (29 mi) & ${ }^{3} \mathrm{H}^{(\mathrm{c})}$ & 54 \\
\hline RWMS-5 & None & 36 km (22 mi) & ${ }^{3} \mathrm{H}^{(\mathrm{c})}$ & 19 \\
\hline Schooner & None & 20 km (12 mi) & ${ }^{3} \mathrm{H}^{(\mathrm{c})}$ & 77 \\
\hline Sedan & None & 50 km (31 mi) & ${ }^{3} \mathrm{H}^{(\mathrm{d})}$ & 85 \\
\hline Area 5 Sewage Lagoon & None & 36 km (22 mi) & ${ }^{3} \mathrm{H}^{(\mathrm{b})}$ & 0.0003 \\
\hline \multicolumn{5}{|l|}{ Grouped Area Sources } \\
\hline All NTS Areas & None & $20-60$ km (12-37 mi) & ${ }^{241} \mathrm{Am}^{(\mathrm{d})}$ & 0.047 \\
\hline All NTS Areas & None & $20-60 \mathrm{~km}(12-37 \mathrm{mi})$ & ${ }^{239+240} \mathrm{Pu}^{(\mathrm{d})}$ & 0.29 \\
\hline
\end{tabular}

(a) All locations are at or near the NTS except Building A-1, in North Las Vegas.

(b) Emission based on tritiated water discharged into containment pond(s)

(c) Emission based on environmental surveillance results and CAP88-PC software

(d) Sum of emissions estimated from re-suspension model; see Table E.1 for individual area estimates 
A summary of the NTS total CY 2006 emissions for NESHAP reporting, by radionuclide, is provided in Table 3.0.

Table 3.0 Total Estimated NTS Emissions for CY 2006 (Multiply Ci by 37 to obtain GBq)

\begin{tabular}{|c|c||}
\hline Radionuclide & 2006 Total Quantity (Ci) \\
\hline${ }^{3} \mathrm{H}$ & 245 \\
${ }^{234} \mathrm{U}$ & 0.000108 \\
${ }^{235} \mathrm{U}$ & 0.000004 \\
${ }^{236} \mathrm{U}$ & 0.000001 \\
${ }^{238} \mathrm{U}$ & 0.000002 \\
${ }^{241} \mathrm{Am}$ & 0.047 \\
${ }^{239+240} \mathrm{Pu}$ & 0.29 \\
\hline
\end{tabular}

Note: This table includes most conservative point and diffuse source release estimates. 


\section{SECTION III DOSE ASSESSMENTS}

\section{DOSE ASSESSMENT METHOD}

Estimating public dose from NTS emissions has been done by two methods since 2001 . The most direct method involves comparisons of radionuclide concentrations measured at air sampling locations near the NTS borders and areas of known potential sources of emissions with concentrations listed in Table 2, Appendix E of 40 CFR 61. Beginning in July 2001, the following air sampling stations were established on the NTS (see Figure 2.0) and were approved by EPA Region IX (EPA, 2001) as critical receptor locations or compliance stations:

Area 6, Yucca

Area 10, Gate 700

Area 16, Substation 3545

Area 20, Schooner

Area 23, Mercury Track

Area 25, Gate 510

Although there are no actual receptors (members of the public) at these locations because they are on the NTS, they are used as such to conservatively represent hypothetical offsite critical receptors. Compliance with the NESHAP inhalation dose limit to the public of $10 \mathrm{mrem} / \mathrm{yr}$ is demonstrated if the measured concentration of each radionuclide at each of these locations is less than the NESHAP Concentration Levels for Environmental Compliance (CL). The CLs represent the annual average concentration of each radionuclide which would result in an effective dose equivalent (EDE) of $10 \mathrm{mrem} / \mathrm{yr}$ (see Table 4.0). If multiple radionuclides are detected at a station, then compliance with NESHAP is demonstrated when the sum of the fractions (determined by dividing each radionuclide's concentration by its CL and then adding the fractions together) is less than 1.0. The comparisons for 2006 air sampling results from the six compliance stations are presented in Table 4.0.

The second method uses the estimates of annual emissions (as shown in Table 3.0), NTS meteorological data, distances of communities from the NTS, and an atmospheric dispersion model. Air dispersion and potential dose is estimated from all releases for all populated areas within $80 \mathrm{~km}$ of the NTS. From 1992 through 2004, this method was used for NESHAP dose assessment using the EPA-approved CAP88-PC software. Dose assessments from the individual emissions using CAP88-PC software were continued from 2001 through 2004 during the transition to the use of the critical receptor location (air sampling) method. The CAP88-PC model produces an estimate of the EDE to the maximally exposed individual (MEI) and identifies in which community surrounding the NTS the MEI resides. The EDE to the MEI has been consistently low over the years 1992-2004 (<0.2 mrem/yr) (Figure 3.0). The MEI has usually been identified as residing in Springdale or Cactus Springs, Nevada.

Title 40 CFR Part 61.93(b)(5) allows the measurement of radionuclide air concentrations at EPA-approved critical receptor locations to be an acceptable alternative to using air dispersion calculations with CAP88-PC software; this method was approved for use at the NTS by the EPA and by DOE Headquarters. The use of critical receptor locations was the only method used in 2006, and therefore only the 2006 results of air sampling at these locations are presented to assess compliance with NESHAP. The MEI, in a sense, may now be considered to hypothetically reside at the onsite critical receptor locations (the air sampling stations), a much more conservative assumption for public exposure to NTS radiation. 


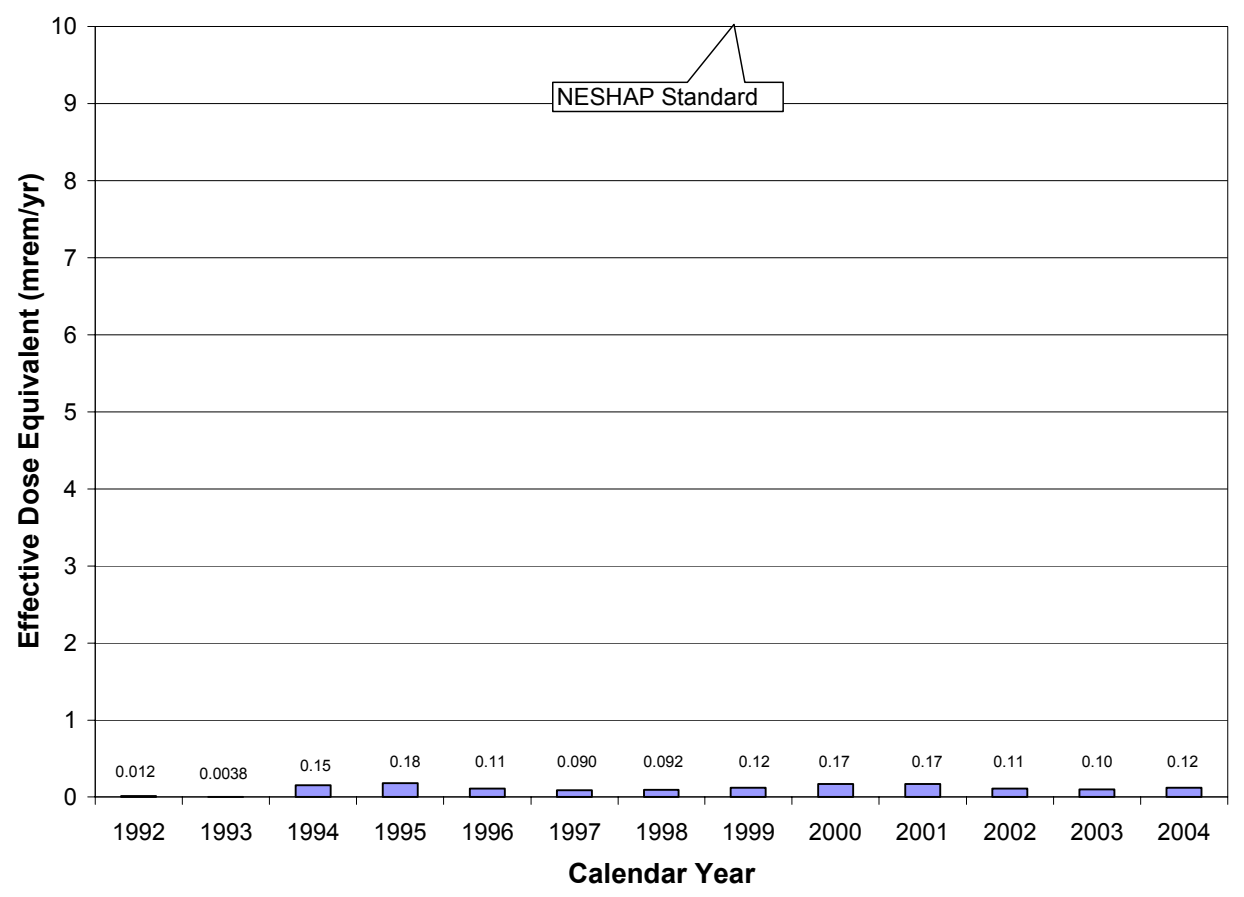

Figure 3.0 Effective dose equivalent to MEI from CYs 1992 to 2004

\section{COMPLIANCE ASSESSMENT}

Table 4.0 lists the average concentrations of detected radionuclides and their fraction of the NESHAP compliance level for each of the six NTS compliance stations. Concentration averages for each detected man-made radionuclide were below three percent of the compliance levels except for the tritium average at the Schooner sampler station, which was 24 percent. The average concentration of tritium is high at Schooner because the air sampler is only 269 meters $(m)$ from the center of the crater and located within the area that received ejecta from the cratering experiment (Figure 4.0). At the Schooner station, the highest sum of the fractions of measured annual concentrations divided by the NESHAP CL for each radionuclide was 0.25 , well below 1.0 and therefore in compliance with NESHAP. This means that the measured equivalent dose from air emissions for an individual who lives year-round at this station would be only $2.5 \mathrm{mrem} / \mathrm{yr}$. Even if one added the measured equivalent doses across all six of the critical receptor sites, it would be only $3.1 \mathrm{mrem} / \mathrm{yr}$. No one resides at Schooner or along the borders near the air sampling stations. The dose at offsite populated locations $20-80 \mathrm{~km}$ (12-50 mi) from the Schooner station would be much lower due to wind dispersion, and likely much less than $1 \mathrm{mrem} / \mathrm{yr}$, similar to the doses estimated since 1992 (see Figure 3.0). 
Table 4.0 Measured Radionuclide Concentrations at NTS Compliance Sampling Stations

\begin{tabular}{|c|c|c|c|c|}
\hline Location & Radionuclide & $\begin{array}{l}\text { Average Concentration } \\
\left(\mathrm{pCi} / \mathrm{m}^{3}\right)\end{array}$ & $\mathrm{CL}\left(\mathrm{pCi} / \mathrm{m}^{3}\right)^{(a)}$ & $\begin{array}{c}\text { Average Concentration as } \\
\text { Fraction of } \mathrm{CL}\end{array}$ \\
\hline Yucca & \multirow{6}{*}{${ }^{3} \mathrm{H}$} & $0.60 \times 10^{-0}$ & \multirow{6}{*}{1500} & 0.0004 \\
\hline Gate 700 & & $0.76 \times 10^{-0}$ & & 0.0005 \\
\hline Substation 3545 & & $0.37 \times 10^{-0}$ & & 0.0002 \\
\hline Schooner & & $365.95 \times 10^{-0}$ & & 0.244 \\
\hline Mercury & & $0.32 \times 10^{-0}$ & & 0.0002 \\
\hline Gate 510 & & $0.33 \times 10^{-0}$ & & 0.0002 \\
\hline Yucca & \multirow{3}{*}{${ }^{233+234} U^{(b)}$} & $1.68 \times 10^{-4}$ & \multirow{3}{*}{0.0071} & 0.0237 \\
\hline Substation 3545 & & $1.74 \times 10^{-4}$ & & 0.0245 \\
\hline Gate 510 & & $1.75 \times 10^{-4}$ & & 0.0247 \\
\hline Yucca & \multirow{3}{*}{${ }^{235+236} U^{(b)}$} & $0.13 \times 10^{-4}$ & \multirow{3}{*}{0.0071} & 0.0018 \\
\hline Substation 3545 & & $0.12 \times 10^{-4}$ & & 0.0017 \\
\hline Gate 510 & & $0.11 \times 10^{-4}$ & & 0.0015 \\
\hline Yucca & \multirow{3}{*}{${ }^{238} U^{(b)}$} & $1.60 \times 10^{-4}$ & \multirow{3}{*}{0.0083} & 0.0192 \\
\hline Substation 3545 & & $1.65 \times 10^{-4}$ & & 0.0199 \\
\hline Gate 510 & & $1.66 \times 10^{-4}$ & & 0.0201 \\
\hline Yucca & \multirow{6}{*}{${ }^{241} \mathrm{Am}$} & $10.33 \times 10^{-6}$ & \multirow{6}{*}{0.0019} & 0.0054 \\
\hline Gate 700 & & $2.02 \times 10^{-6}$ & & 0.0011 \\
\hline Substation 3545 & & $8.12 \times 10^{-6}$ & & 0.0043 \\
\hline Schooner & & $4.31 \times 10^{-6}$ & & 0.0023 \\
\hline Mercury & & $2.38 \times 10^{-6}$ & & 0.0013 \\
\hline Gate 510 & & $2.94 \times 10^{-6}$ & & 0.0015 \\
\hline Yucca & \multirow{6}{*}{${ }^{238} \mathrm{Pu}$} & $2.27 \times 10^{-6}$ & \multirow{6}{*}{0.0021} & 0.0011 \\
\hline Gate 700 & & $1.24 \times 10^{-6}$ & & 0.0006 \\
\hline Substation 3545 & & $3.79 \times 10^{-6}$ & & 0.0018 \\
\hline Schooner & & $1.33 \times 10^{-6}$ & & 0.0006 \\
\hline Mercury & & $-0.26 \times 10^{-6}$ & & -0.0001 \\
\hline Gate 510 & & $0.45 \times 10^{-6}$ & & 0.0002 \\
\hline Yucca & \multirow{6}{*}{${ }^{239+240} \mathrm{Pu}$} & $49.7 \times 10^{-6}$ & \multirow{6}{*}{0.0020} & 0.0248 \\
\hline Gate 700 & & $14.4 \times 10^{-6}$ & & 0.0072 \\
\hline Substation 3545 & & $17.0 \times 10^{-6}$ & & 0.0085 \\
\hline Schooner & & $4.55 \times 10^{-6}$ & & 0.0023 \\
\hline Mercury & & $2.18 \times 10^{-6}$ & & 0.0011 \\
\hline Gate 510 & & $2.48 \times 10^{-6}$ & & 0.0012 \\
\hline Yucca & \multirow{6}{*}{$\begin{array}{l}\text { Sum of } \\
\text { Fractions by } \\
\text { Location }\end{array}$} & & & 0.0764 \\
\hline Gate 700 & & & & 0.0094 \\
\hline Substation 3545 & & & & 0.0609 \\
\hline Schooner & & & & 0.2492 \\
\hline Mercury & & & & 0.0025 \\
\hline Gate 510 & & & & 0.0494 \\
\hline
\end{tabular}

(a) Source: Table 2 in Title 40 CFR 61, Appendix E (Compliance Procedures Methods for Determining Compliance with Subpart I)

(b) No radiochemical analysis for uranium at stations Gate 700, Schooner, or Mercury. 


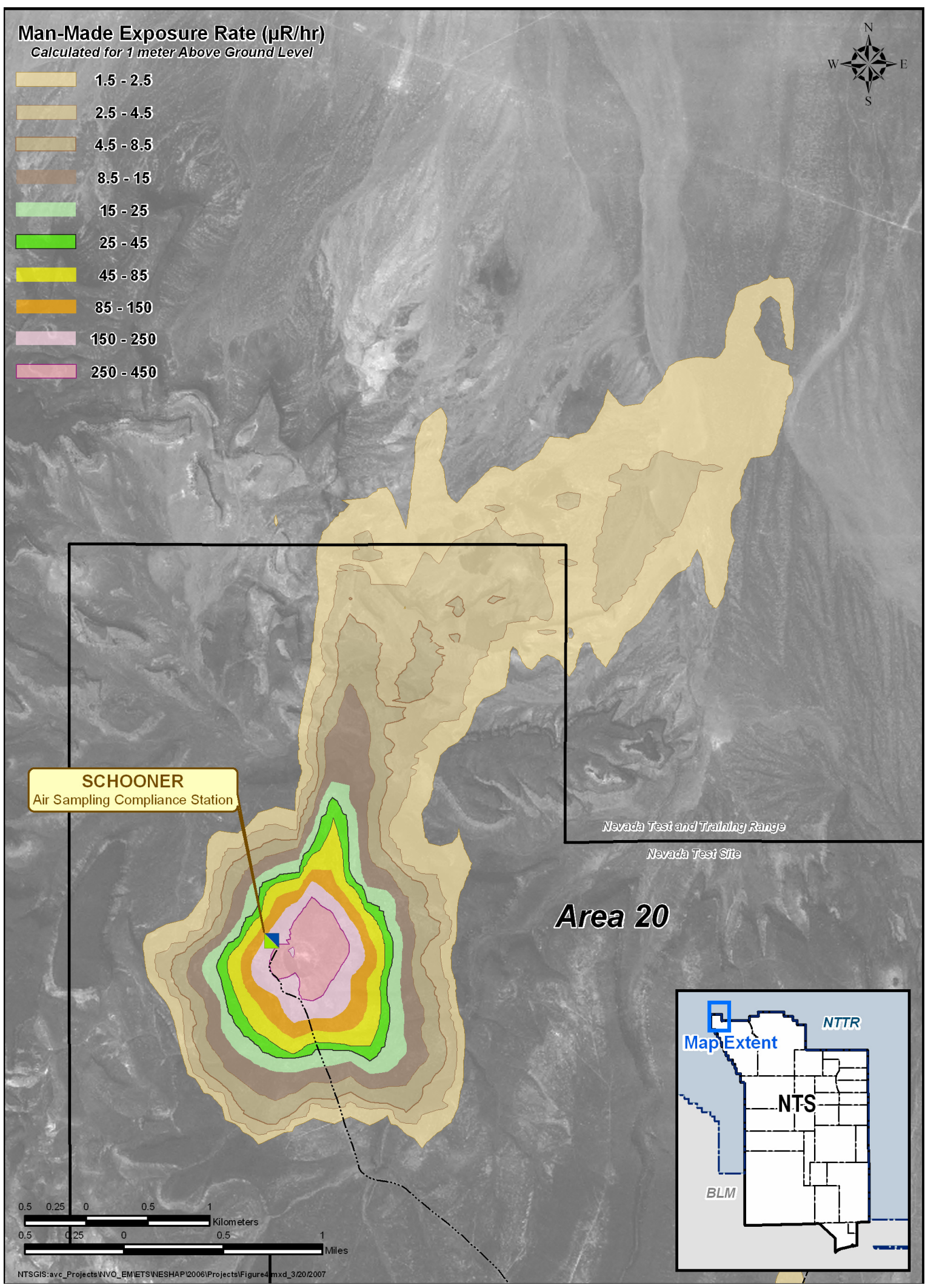

Figure 4.0 Schooner Air Sampling Compliance Station 


\section{SECTION IV \\ ADDITIONAL INFORMATION}

NEW CONSTRUCTION/MODIFICATION ACTIVITIES AT THE NTS

Several projects were evaluated to determine if they have the potential to release airborne radionuclides which would expose the public to a dose greater than $0.1 \mathrm{mrem} / \mathrm{yr}$. For any project or facility with this potential, the EPA requires point-source operational monitoring. These projects are identified below with a brief summary of the evaluations. More detailed descriptions of the dose evaluations can be found in Appendix F.

- $\quad$ Corrective Action Unit (CAU) 214 consists of nine corrective action sites located in Areas 5,11 , and 25 of the NTS (DOE, 2005). A dose assessment was done for soil excavation from Area 5 of the NTS. The primary radionuclide identified in soil to be excavated was ${ }^{152} \mathrm{Eu}$ at $3.92 \mathrm{pCi} / \mathrm{g}$. Using an EPA-defined emission factor for soil removal and haulage (EPA, 2004) it was estimated that there was potential for $4,500 \mathrm{pCi}$ of ${ }^{152} \mathrm{Eu}$ to be emitted to air. CAP88-PC dose estimates using CY 2006 wind data from the closest meteorological station resulted in an estimated EDE of $2.6 \times 10^{-12} \mathrm{mrem} / \mathrm{yr}$ at the closest populated location offsite (American Cement / Aggregate) $25.6 \mathrm{~km}$ (15.9 mi) south of the emission.

- A series of experiments planned by the Dense Plasma Focus (DPF) project in Area 11, Building 11-102, was evaluated. Though there are no immediate plans to use tritium in the experiments, an evaluation was done using CAP88-PC where 2 kilocuries $(\mathrm{kCi})$ of tritium gas was expected to be released and oxidize to HTO. The EDE to the MEI was estimated to be only $0.00086 \mathrm{mrem} / \mathrm{yr}$ at Cactus Springs, $46 \mathrm{~km}$ (29 mi) south of Building 11-102. No experiments were conducted during 2006.

- Construction activities planned as part of the Legacy Compliance Project included the construction of flood control structures in radiologically impacted portions of Area 8 on the NTS. Because surface soils contain man-made radionuclides, an estimate of potential emissions to air was made specifically for grading, excavation, and the construction of structures or berms to control runoff from the site. The radionuclide of primary concern was ${ }^{239} \mathrm{Pu}$, given its concentration and potential for dose being higher than other radionuclides present. Using an EPA defined emission factor for soil removal and haulage (EPA, 2004) and scaling the release amount to a previous dose assessment resulted in an estimated EDE of $4 \times 10^{-7} \mathrm{mrem} / \mathrm{yr}$ to the MEl at Amargosa Valley $67.5 \mathrm{~km}$ (42 mi) south-southwest of the construction site. While this assessment was conducted in 2006, construction was not completed by the end of 2006.

\section{UNPLANNED RELEASES DURING CY 2006}

No unplanned releases occurred during 2006. 


\section{SOURCES OF DIFFUSE OR FUGITIVE EMISSIONS}

In summary, all sources of radionuclide emissions from the NTS or the NLVF identified and characterized in 2006 included the following:

- Evaporation of tritiated water from the Building A-1 basement at the NLVF (see Appendix A)

- Evaporation of tritium from Area 5 Sewage Lagoon, which received liquid effluents from the Building A-1 basement at the NLVF, and from E Tunnel containment ponds in Area 12, which received water seeping from the Tunnel complex (see Appendix $B$ )

- Release of tritium gas during the calibration of analytical equipment in Building 650 in Mercury (see Appendix C)

- Evapotranspiration of tritium from the Sedan and Schooner craters and from the areas including the Area 3 and Area 5 RWMSs (see Appendix D)

- Re-suspension of ${ }^{241} \mathrm{Am}$ and ${ }^{239+240} \mathrm{Pu}$ from soil deposits on the NTS areas (see Appendix E)

- Miscellaneous environmental restoration, research, and construction projects resulting in the emission of low amounts of radionuclides (see Appendix F) 


\section{CERTIFICATION}

I certify under penalty of law that I have personally examined and am familiar with the information submitted herein and based on my inquiry of those individuals immediately responsible for obtaining the information, I believe that the submitted information is true, accurate and complete. I am aware that there are significant penalties for submitting false information including the possibility of fine and imprisonment. See 18 U.S.C. 1001.

Name: Gerald L. Talbot, Manager, NNSA/NSO

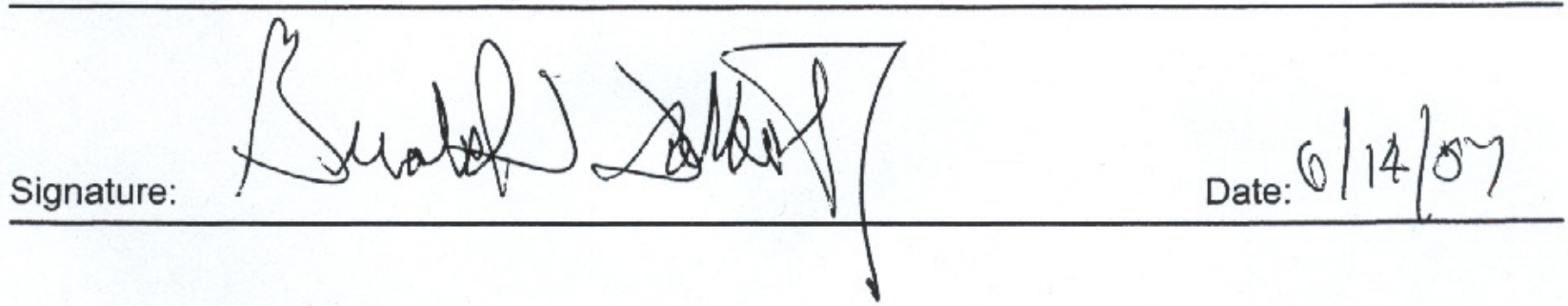


This page intentionally left blank 


\section{REFERENCES}

Code of Federal Regulations, 2002, National Emission Standards for Hazardous Air Pollutants: Radionuclides, Title 40 CFR Part 61, U.S. Environmental Protection Agency, Washington, D.C.

DOE, see U.S. Department of Energy.

Energy Research and Development Administration, 1977, Final Environmental Impact Statement, Nevada Test Site, Nye County, Nevada, Report ERDA-1551, Washington, D.C.

EPA, see U.S. Environmental Protection Agency.

Federal Facility Agreement and Consent Order (FFACO), 1996, An FFACO among the state of Nevada, the U.S. Department of Energy, and the U.S. Department of Defense, May 1996.

National Security Technologies, LLC, 2007, 2006 Waste Management Monitoring Report, Area 3 and Area 5 Radioactive Waste Management Sites, Report in Preparation, National Security Technologies, LLC, Las Vegas, NV, June, 2007.

NRC, see U.S. Nuclear Regulatory Commission.

NSTec, see National Security Technologies, LLC.

Shott, G. J., L. E. Barker, S. E. Rawlinson, M. J. Sully, and B. A. Moore, 1998, Performance Assessment for the Area 5 RWMS at the NTS, Nye County, Nevada, Revision 2.1, Report DOE/NV/11718--176, Bechtel Nevada, Las Vegas, NV.

U.S. Department of Energy, 1991, Radionuclides in Surface Soil at the Nevada Test Site, Report DOE/NV/10845--02, Water Resources Center, Desert Research Institute, University of Nevada System, Las Vegas, NV.

U.S. Department of Energy, 1992, Summary of the Nevada Applied Ecology Group and Correlative Programs, Report DOE/NV--357, Raytheon Services Nevada, Las Vegas, NV.

U.S. Department of Energy, 1996a, Final Environmental Impact Statement for the Nevada Test Site and Off-Site Locations in the State of Nevada, Report DOE/EIS 0243, Nevada Operations Office, Las Vegas, NV.

U.S. Department of Energy, 1996b, National Emission Standards for Hazardous Air Pollutants Submittal - 1995, Report DOE/NV/11718--032, Nevada Operations Office, Las Vegas, NV.

U.S. Department of Energy, 2000, United States Nuclear Tests: July 1945 through September 1992, Report DOE/NV--209 (Revision 15), Nevada Operations Office, Las Vegas, NV.

U.S. Department of Energy, 2002, Underground Test Area Project Waste Management Plan, Report DOE/NV--343-Rev 2, Nevada Operations Office, Las Vegas, NV.

U.S. Department of Energy, 2003, Routine Radiological Environmental Monitoring Plan, Report DOE/NV/11718--804, Nevada Operations Office, Las Vegas, NV. 
U.S. Department of Energy, 2004a, E-mail from Gustavo Vazquez, DOE/EH-41, to Bruce W. Hurley, NNSA/NVO, dated April 1, 2004.

U.S. Department of Energy, 2004b, Quality Assurance, DOE Order 414.1B, April 29, 2004, Washington, D.C.

U.S. Department of Energy, 2005, Corrective Action Plan for Corrective Action Unit 214:

Bunkers and Storage Areas, Nevada Test Site, Nevada, Report DOE/NV--1040, Nevada Operations Office, Las Vegas, NV.

U.S. Environmental Protection Agency, 2001, Test Methods for Measuring Radionuclide Emissions from Stationary Sources, Title 40 Code of Regulations, Part 61, Appendix B, Method 114, July 1, 2001 Edition.

U.S. Environmental Protection Agency, 2004, Methods for Estimating Fugitive Air Emissions of Radionuclides from Diffuse Sources at DOE Facilities. EPA Final Report September 3, 2004. Office of Radiation and Indoor Air, Washington, D.C.

U.S. Environmental Protection Agency, 2006, Updated User's Guide for CAP88-PC, Version 3.0, Office of Radiation and Indoor Air, Washington, D.C.

U.S. Nuclear Regulatory Commission, 1983, Radiological Assessment, Report NUREG/CR3332, Till, J. E., and H. R. Meyer, Editors, Office of Nuclear Reactor Regulation, Washington, D.C. 
This page intentionally left blank 


\section{APPENDIX A}

\section{PUBLIC DOSE CALCULATIONS FOR THE RELEASE OF TRITIUM FROM THE A-1 BUILDING, NLVF}

As discussed in the 1995 National Emission Standard for Hazardous Air Pollutants (NESHAP) report (DOE, 1996b), a container of tritium-aluminum foils was opened in the Atlas Facility at the North Las Vegas Facility (NLVF) area and emitted at least 1 curie (Ci) of tritium into a basement area used as a fixed radiation source range. Environmental surveillance began on Friday, July 14, 1995, the day notification of the tritium leak occurred. Environmental tritiated water (HTO) samplers were installed at three locations outside the facility. Later, an HTO sampler was installed in the basement and operated continuously so that progress on cleanup of the spill could be monitored. After cleanup began, the environmental samplers were removed, but the basement air sampler continued operation through January 5, 1998, at which time samples were collected once each quarter. The 1996, 1997, and 1998 results and effective dose equivalent $(\mathrm{EDE})$ to the maximally exposed individual (MEI) offsite at the perimeter fence were reported in the annual NESHAP reports.

During the years 1999 through 2006, air sampling for HTO in the basement was conducted intermittently. For calendar year (CY) 2006, the result of one atmospheric moisture sample collected September 12 to September 19, 2006 (660 picocuries per cubic meter $\left[\mathrm{pCi} / \mathrm{m}^{3}\right]$ ), and the basement ventilation rate of 673 cubic feet per minute $\left(\mathrm{ft}^{3} / \mathrm{min}\right)$, were used to estimate the annual tritium emission: 1,220 (average 2003-2006) $\mathrm{pCi} / \mathrm{m}^{3} \times 673 \mathrm{ft}^{3} / \mathrm{min} \times 0.02832 \mathrm{~m}^{3} / \mathrm{ft}^{3} \times$ $525,600 \mathrm{~min} /$ year $(\mathrm{yr}) \times 10^{-9} \mathrm{milli}-$ curies $(\mathrm{mCi}) / \mathrm{pCi}=12 \mathrm{mCi} / \mathrm{yr}$. An additional $1.2 \mathrm{mCi}$ of tritium was released from Building A-1 by evaporating water from the radiation source well, resulting in a total emission of $13.2 \mathrm{mCi}$. The Clean Air Package 1988 (CAP88-PC) average dose factor used for dose assessments from 1995 to $2001\left(5.0 \times 10^{-6} \mathrm{mrem} / \mathrm{yr} / \mathrm{mCi}\right)$ was multiplied with this emission to obtain the EDE $(0.07 \mu \mathrm{rem} / \mathrm{yr})$ to the nearest member of the public outside the perimeter fence of Building A-1. A comparison of the past and current emission rates and radiation dose to the $\mathrm{MEI}$ are presented in Table A.1.

Table A.1 Comparison of Tritium Emission Rates from 1995-2006

\begin{tabular}{||c|c|c||}
\hline \hline Year & $\begin{array}{c}\text { Tritium Emission Rate } \\
(\mathbf{m C i} / \mathbf{y r})\end{array}$ & $\begin{array}{c}\text { EDE to MEI } \\
(\boldsymbol{\mu r e m} / \mathbf{y r})\end{array}$ \\
\hline 1995 & 123 & 0.96 \\
1996 & 52 & 0.25 \\
1997 & 110 & 0.53 \\
1998 & 16 & 0.08 \\
1999 & 301 & 1.4 \\
2000 & 370 & 1.8 \\
2001 & 200 & 0.96 \\
2002 & (not sampled) & - \\
2003 & 9.3 & - \\
2004 & 11 & - \\
2005 & 20 & 0.10 \\
2006 & 13.2 & 0.07 \\
\hline
\end{tabular}


This page intentionally left blank 


\section{APPENDIX B}

\section{CALCULATION OF TRITIUM EMISSIONS FROM NEVADA TEST SITE PONDS}

During calendar year 2006, the air emissions of tritium as tritiated water from Nevada Test Site ponds containing tritium were conservatively estimated from the product of the volume of water discharged into the ponds and measurements of the tritium content of the water. Table B-1 lists the estimates and the values used in the estimates.

Table B.1. Tritium Concentrations and Water Volumes used to Estimate Tritium Emissions from NTS ponds.

\begin{tabular}{|l|c|c|c|}
\hline \multicolumn{1}{|c|}{ Location } & $\begin{array}{c}\text { Tritium } \\
\text { Concentration } \\
(\mathrm{pCi} / \mathrm{L})\end{array}$ & $\begin{array}{c}\text { Water } \\
\text { Volume } \\
(\mathrm{L})\end{array}$ & $\begin{array}{c}\text { Tritium } \\
\text { Emission } \\
(\mathrm{Ci})\end{array}$ \\
\hline E Tunnel Ponds & $6.03 \times 10^{5}$ & $16,278,624$ & 9.8 \\
Area 5 Sewage Lagoon & $1.89 \times 10^{3}$ & 177,623 & 0.0003 \\
\hline
\end{tabular}

Water continues to drain from the E Tunnel into several ponds after attempts failed in the past to seal the tunnel.

The water discharged into the Area 5 Sewage Lagoon was removed from the basement of Building A-1, North Las Vegas Facility, where water in a source well containing tritium, attributed to the contaminating event referred to in Appendix A, was rising due to changes in the groundwater level. 
This page intentionally left blank 


\section{APPENDIX C}

\section{POTENTIAL RADIONUCLIDE EMISSIONS FROM RADIOANALYTICAL LABORATORIES}

\section{Building 650 Source Storage Room}

Following the closure of the Analytical Services Laboratory in Area 23 at Building 650, all of the standards, check sources, and tracer solutions were stored in a basement room until all items could be properly disposed. From an inventory of these radioactivity sources, only three of them, listed below with their curie (Ci) content assessed during calendar year (CY) 2002, are volatile and could become sources of air emissions.

$\begin{array}{ll}\text { Tritium }\left({ }^{3} \mathrm{H}\right)(\text { as tritiated water }) & 3.0 \times 10^{-4} \mathrm{Ci} \\ \text { Krypton-85 }\left({ }^{85} \mathrm{Kr}\right) & 8.7 \times 10^{-2} \mathrm{Ci} \\ \text { lodine-129 }\left({ }^{129} \mathrm{I}\right) & 5.4 \times 10^{-7} \mathrm{Ci}\end{array}$

All of the standards and solutions were maintained in accordance with 10 Code of Federal Regulations 835. No portion of these sources were released or consumed during CY 2006; therefore, no emission from these sources was estimated. However, about 22.5 microcuries $(\mu \mathrm{Ci})$ of tritium gas from a pressurized tank at Building 650 were consumed during the calibration of analytical equipment.

\section{Los Alamos National Laboratory Building CP-95A - Area 6 Lawrence Livermore National Laboratory Device Assembly Facility - Area 6}

In previous years, the laboratories in these facilities maintained standards of radioactivity containing xenon-133 $\left({ }^{133} \mathrm{Xe}\right)$, iodine-131 $\left({ }^{131} \mathrm{I}\right)$, and ${ }^{3} \mathrm{H}$. Due to the test moratorium that began in 1992, the need for standards was reduced. The use of the standards during the year did not result in any release to the atmosphere. 
This page intentionally left blank 


\section{APPENDIX D}

\section{TRITIUM EMISSIONS ESTIMATED FROM AIR SAMPLING DATA}

\section{BACKGROUND INFORMATION}

Environmental monitoring for tritium in atmospheric moisture was conducted at ten locations on the Nevada Test Site (NTS) until July 2001. Then the number of monitoring locations was increased to 14 , and some of the locations were changed to conform to a change in strategy for demonstrating compliance with National Emission Standard for Hazardous Air Pollutants (see Compliance Assessment in Section III). There were four air samplers around the perimeter of the Area 5 Radioactive Waste Management Site (RWMS) where many curies (Ci) of tritium are buried at that facility; however, all four samplers were removed because they were too close to the sources for them to be used with the Clean Air Package 1988 computer program (CAP88-PC) software in estimating the tritium emissions. Instead, air samplers identified as U.S. Department of Defense (DoD) and Sugar Bunker North were added 1,590 meters $(5,216$ feet) north and 970 meters $(3,182$ feet) south, respectively, of the compound within the prevailing downwind sectors of the facility. Other air samplers were operated at the $E$ Tunnel ponds area, near Sedan crater, and near Schooner crater. In November 2004, tritium samplers were installed at U-3bh N and U-3ah/at S near the Area 3 RWMS to monitor tritium emissions from waste disposal operations and vicinity. Figure 2.0 of this report shows the current NTS air sampling station locations.

\section{SOURCE TERM ESTIMATES}

Estimating the tritium emissions as tritiated water (HTO) from air sampling data required a CAP88-PC estimate of the air concentration at the location of each air sampler for a $1 \mathrm{Ci}$ release from the center of each source location. The total annual emission was then calculated by dividing the annual average concentration of HTO measured at each sampling location by the predicted CAP88-PC concentration for a $1 \mathrm{Ci}$ release. An estimate of the emissions based on vegetation samples was not made in 2006.

Table D.1 lists the estimated emissions for each emission source location. Tritium emission from E Tunnel ponds was not estimated from air sampling data because the estimate from the total water pond influent and measured tritium concentrations, as described in Appendix B, was more conservative. 
Table D.1 Tritium Emissions from Airborne Tritium Sampling Results during 2006

\begin{tabular}{||c|c|c|c|c||}
\hline $\begin{array}{c}\text { Emission } \\
\text { Source }\end{array}$ & Air Sampler & $\begin{array}{c}\text { Tritium } \\
\text { Concentration } \\
\left(\mathbf{p C i} / \mathbf{m}^{\mathbf{3}} \mathbf{)}\right.\end{array}$ & $\begin{array}{c}\text { CAP88-PC } \\
\text { Concentration } \\
\text { for 1 Ci } \\
\text { Emission }\end{array}$ & $\begin{array}{c}\text { Tritium } \\
\text { Emission } \\
(\mathbf{C i})^{(\mathbf{a})}\end{array}$ \\
\hline \multirow{3}{*}{ Area 3 RWMS } & BJY & 1.24 & 0.023 & $54^{(\mathrm{b})}$ \\
\cline { 2 - 5 } & U-3bh North & 0.69 & 0.840 & 0.8 \\
\hline \multirow{2}{*}{ Area 5 RWMS } & Doh/at South & 1.36 & 0.309 & 4.4 \\
\cline { 2 - 5 } & Sugar Bunker North & 4.04 & 0.150 & $19^{(\mathrm{c})}$ \\
\hline \multirow{2}{*}{ Area 10 Sedan } & Sedan North & 9.52 & 0.588 & $7^{(\mathrm{c})}$ \\
\cline { 2 - 5 } & Gate 700 & 0.76 & 0.198 & $48^{(\mathrm{c})}$ \\
\hline \multirow{2}{*}{ Area 20 Schooner } & Schooner & 366 & 0.398 & $95^{(\mathrm{c})}$ \\
\cline { 2 - 5 } & Gate 20-2P & 0.37 & 0.00479 & $70^{(\mathrm{d})}$ \\
\hline
\end{tabular}

(a) $1 \mathrm{Ci}=37$ Giga-becquerels (GBq)

(b) Emission estimate likely biased high due to sampler potentially measuring tritium from other sources. Estimate still used for conservatism.

(c) The higher of the two emission estimates for each location was used for that location

(d) Emission estimate likely biased high due to sampler being too close to the diffuse emission source. Alternative emission estimate based on Gate 20-2P sampling location considered more defensible and therefore used. 


\section{APPENDIX E}

\section{EMISSIONS OF AMERICIUM AND PLUTONIUM FROM LEGACY SITES BASED ON HISTORIC SOIL SURVEY DATA AND SOIL RE-SUSPENSION MODEL}

\section{BACKGROUND INFORMATION}

Areas 1 through 12 and Areas 15 through 30 on the Nevada Test Site (NTS) contain diffuse sources of radionuclides. Historic soil surveys have identified the location of these sources on the NTS and provided estimates of the amounts of radionuclides which remain in the surface soils (DOE, 1991; see Table 1.0). Due to occasional high winds, some contaminated soil becomes airborne. Results from the air samplers in these areas indicate that americium-241 $\left({ }^{241} \mathrm{Am}\right)$ and plutonium-239+240 $\left({ }^{239+240} \mathrm{Pu}\right)$ are routinely detected, but only in concentrations slightly above the minimum detectable concentration (MDC). The total emissions (in curies [Ci]) produced each year from all known soil legacy sites on the NTS is estimated. This appendix describes all the calculations involved in producing the emission estimates.

\section{RE-SUSPENSION CALCULATIONS}

These calculations are needed to estimate how much of the radionuclides in surface soils could actually become airborne (re-suspended) and therefore become an emission. A conservative estimate of americium and plutonium emissions from diffuse sources is obtained by the use of a re-suspension equation with parameters derived from actual studies at the NTS. In NUREG/CR3332 (NRC, 1983), page 5-30, an equation for calculating a suspension rate (fraction resuspended per second) is given as follows:

$$
\mathrm{S}=\mathrm{K} \times \mathrm{V}_{\mathrm{g}}
$$

where: $S$ = fractional re-suspension rate (curies per second [Ci/s]), or the fraction of the inventory re-suspended per second

$\mathrm{K}=$ re-suspension factor (per meter $[\mathrm{m}]$ )

$\mathrm{V}_{\mathrm{g}}=$ deposition velocity (meters per second $[\mathrm{m} / \mathrm{s}]$ )

The values of $\mathrm{K}$ and $\mathrm{V}_{\mathrm{g}}$ used in this re-suspension equation are taken from DOE (1992). On page 75 of DOE (1992), values of K are given for the NTS. An average of the values is $2 \times 10^{-10} / \mathrm{m}$. Ranges in $V_{g}$ of 0.01 to $0.05 \mathrm{~m} / \mathrm{s}$, presented in DOE (1992), are used as conservative estimates. When these values are put into the above equation, $S$ is between $2 \mathrm{x}$ $10^{-12}$ and $1 \times 10^{-11} / \mathrm{s}$. To be conservative, the higher fractional re-suspension rate of $1 \times 10^{-11} / \mathrm{s}$ is used. For example, the emission rate in pico-curies $(\mathrm{pCi}) / \mathrm{s}$ for ${ }^{239+240} \mathrm{Pu}$ from Area 3 is calculated from the product of the ${ }^{239+240} \mathrm{Pu}$ inventory ( $37 \mathrm{Ci}$ from Table 1.0 ) and $\mathrm{S}$ as follows:

$$
(37 \mathrm{Ci}) \times\left(1 \times 10^{-11} / \mathrm{s}\right) \times\left(10^{12} \mathrm{pCi} / \mathrm{Ci}\right)=370 \mathrm{pCi} / \mathrm{s}
$$

Since 1 year $(y r)=3,600 \mathrm{~s} /$ hour $\times 24$ hour/day $\times 365$ days $/ y r=3.15 \times 10^{7} \mathrm{~s} / \mathrm{yr}$, the annual emission rate becomes:

$$
370 \mathrm{pCi} / \mathrm{s} \times 3.15 \times 10^{7} \mathrm{~s} / \mathrm{yr}=1.17 \times 10^{10} \mathrm{pCi} / \mathrm{yr} \text { or } 11.7 \text { millicuries }(\mathrm{mCi}) / \mathrm{yr}
$$

This method was used for calculating the ${ }^{241} \mathrm{Am}$ and ${ }^{239+240} \mathrm{Pu}$ emissions from all other areas. The results are shown in Table E.1. 
Table E.1 Calculated Emissions from Inventories ${ }^{(a)}$ of Plutonium and Americium in NTS Areas

\begin{tabular}{|c|c|c|c|c|c|c|}
\hline \multicolumn{7}{|c|}{ Inventory, Re-suspension Factors, and Calculated Emissions by Area } \\
\hline Area & $\begin{array}{l}{ }^{241} \mathrm{Am} \\
(\mathrm{Ci})\end{array}$ & $\begin{array}{c}{ }^{239+240} \mathrm{Pu} \\
(\mathrm{Ci})\end{array}$ & $\underset{\left(m^{-1}\right)}{K}$ & $\begin{array}{c}\mathrm{Vg} \\
(\mathrm{m} / \mathrm{s})\end{array}$ & $\begin{array}{c}\text { Emissions } \\
\text { of }{ }^{241} \mathrm{Am} \\
(\mathrm{mCi} / \mathrm{yr})\end{array}$ & $\begin{array}{c}\text { Emissions } \\
\text { of }{ }^{239+240} \mathrm{Pu} \\
(\mathrm{mCi} / \mathrm{yr})\end{array}$ \\
\hline 1 & 4.2 & 24 & 2.E-10 & $5 . E-02$ & 1.32 & 7.6 \\
\hline 2 & 2.9 & 22 & 2.E-10 & $5 . E-02$ & 0.91 & 6.9 \\
\hline 3 & 4.6 & 37 & 2.E-10 & 5.E-02 & 1.45 & 11.7 \\
\hline 4 & 6.6 & 40 & 2.E-10 & 5.E-02 & 2.08 & 12.6 \\
\hline 5 & 0.6 & 4.8 & 2.E-10 & 5.E-02 & 0.19 & 1.5 \\
\hline 6 & 1.7 & 8.4 & 2.E-10 & 5.E-02 & 0.54 & 2.6 \\
\hline 7 & 2.2 & 16 & 2.E-10 & 5.E-02 & 0.69 & 5.0 \\
\hline 8 & 17 & 110 & 2.E-10 & 5.E-02 & 5.36 & 34.7 \\
\hline 9 & 4.2 & 89 & 2.E-10 & 5.E-02 & 1.32 & 28.0 \\
\hline 10 & 19 & 110 & 2.E-10 & 5.E-02 & 5.99 & 34.7 \\
\hline 11 & 3.3 & 29 & 2.E-10 & 5.E-02 & 1.04 & 9.1 \\
\hline 12 & 5.7 & 39 & 2.E-10 & 5.E-02 & 1.80 & 12.3 \\
\hline 15 & 8.0 & 63 & 2.E-10 & 5.E-02 & 2.52 & 19.8 \\
\hline 16 & 0.7 & 3.7 & 2.E-10 & 5.E-02 & 0.22 & 1.2 \\
\hline 17 & 2.8 & 18 & 2.E-10 & 5.E-02 & 0.88 & 5.7 \\
\hline 18 & 19 & 100 & 2.E-10 & 5.E-02 & 5.99 & 31.5 \\
\hline 19 & 21 & 140 & 2.E-10 & 5.E-02 & 6.62 & 44.1 \\
\hline 20 & 23 & 41 & 2.E-10 & 5.E-02 & 7.25 & 12.9 \\
\hline 30 & 3.2 & 14 & 2.E-10 & 5.E-02 & 1.01 & 4.4 \\
\hline TOTAL & 140 & 910 & & & 47 & 290 \\
\hline
\end{tabular}

(a) Radioactive inventories from Table 5 in DOE/NV/10845--02 (DOE, 1991)

As shown in Table E.1, the estimated total emissions of ${ }^{241} \mathrm{Am}$ and ${ }^{239+240} \mathrm{Pu}$ from historic soil inventory data and from the re-suspension model were 47 and $290 \mathrm{mCi} / \mathrm{yr}$, respectively. These are shown in Table 2.0 (as 0.047 and $0.29 \mathrm{Ci} / \mathrm{yr}$ ), which summarizes all measured or computed emissions from the NTS in 2006.

\section{OTHER ISOTOPES}

The other isotopes that have been found in soil samples in the various areas on the NTS are cobalt-60 ( $\left.{ }^{60} \mathrm{Co}\right)$, strontium-90 $\left({ }^{90} \mathrm{Sr}\right)$, cesium-137 $\left({ }^{137} \mathrm{Cs}\right)$, europium-152 $\left({ }^{152} \mathrm{Eu}\right)$, europium-154 $\left({ }^{154} \mathrm{Eu}\right)$, and europium-155 $\left({ }^{155} \mathrm{Eu}\right)$; however, their concentrations in air samples are below detection levels and collectively contribute less than 10 percent to the total dose from all radionuclide emissions calculated from re-suspension calculations, and therefore they have not been included in evaluations for National Emission Standards for Hazardous Air Pollutants compliance. 


\section{APPENDIX F}

\section{RADIONUCLIDE EMISSIONS FROM \\ ENVIRONMENTAL RESTORATION, RESEARCH, OR CONSTRUCTION PROJECTS}

\section{ENVIRONMENTAL CLEANUP PROJECTS}

Corrective Action Unit (CAU) 214 is identified in the Federal Facility Agreement and Consent Order (FFACO) of 1996. CAU 214 consists of nine Corrective Action Sites located in Areas 5, 11, and 25 of the Nevada Test Site (NTS) (DOE, 2005). A dose assessment was done for soil excavation from Area 5 of the NTS. Europium-152 $\left({ }^{152} \mathrm{Eu}\right)$ was identified in soil at 3.92 picocuries per gram (pCi/g). Given 60 cubic meters $\left(\mathrm{m}^{3}\right)$ (79 cubic yards [yd $\left.\left.{ }^{3}\right]\right)$ of soil estimated to be moved and a density of 1.5 grams per cubic centimeter $\left(\mathrm{g} / \mathrm{cm}^{3}\right)$, a total of $9 \times 10^{7} \mathrm{~g}$ of soil were expected to be excavated. Using a United States Environmental Protection Agency (EPA)defined emission factor for soil removal and haulage (EPA, 2004) equal to 0.0128 kilograms $(\mathrm{kg})$ of particulate matter emitted per $1 \times 10^{6} \mathrm{~g}$ of material handled, it was estimated that there was a potential for $4,500 \mathrm{pCi}$ of ${ }^{152} \mathrm{Eu}$ to be emitted. Clean Air Package 1988 (CAP88-PC) dose estimates using calendar year 2006 wind data from the closest meteorological station resulted in an estimated dose of $2.6 \times 10^{-12}$ millirem per year $(\mathrm{mrem} / \mathrm{yr})$ at the closest populated location offsite 25.6 kilometers $(\mathrm{km})$ (15.9 miles [mi]) south of the emission.

\section{RESEARCH PROJECTS}

A multi-organization research project conducted in September 2006, resulted in uranium isotope emissions to air. Total emissions were determined by laboratory analysis and mass balance. Total activities released are listed in Tables F.1. They are also included under Miscellaneous Projects in Table 2.0 in the main body of this report and also in Table 3.0.

The objective of this analysis was to determine the potential effective dose equivalent (EDE) to persons residing downwind from these releases and compare this potential EDE to the dose standards specified in 40 Code of Federal Regulations 61, Subpart $\mathrm{H}$. The CAP-88 model (CAP88-PC, Version 3.0) was used to conduct a dose assessment for this project. Conservative modeling was performed by assuming winds from only one direction to move the materials in a straight line. Potential dose with distance was then compared with the closest NTS boundary $(22.5 \mathrm{~km})$ to estimate the maximum potential offsite dose (though there are no residents at the nearest boundary). The closest offsite resident was a distance of about $35 \mathrm{~km}$. Model parameters used in the modeling were: release height $=3 \mathrm{~m}$; no plume momentum or buoyancy; ambient temperature $=30$ degrees $\mathrm{C}$; humidity $=8 \mathrm{~g} / \mathrm{m}^{3}$; mixing height $=1000 \mathrm{~m}$; wind file created for one direction with a wind speed in range of 7-10 knots (average $=4.4 \mathrm{~m} / \mathrm{s}$ ), and stability class C; rural food scenario (no imported food); and distances of calculated doses at intervals of $4 \mathrm{~km}$ to $80 \mathrm{~km}$.

Table F.1 Research Project Total Activity Released to Air

\begin{tabular}{|c|c|}
\hline Radionuclide & Total Activity (Ci) \\
\hline$U-234$ & 0.000108 \\
\hline$U-235$ & 0.000004 \\
\hline$U-236$ & 0.000001 \\
\hline$U-238$ & 0.000002 \\
\hline
\end{tabular}


Based on the radiation doses estimated by the CAP88-PC model, the EDE to a hypothetical resident at the closest NTS boundary would be $1.2 \times 10^{-5} \mathrm{mrem} / \mathrm{yr}$ (Figure F.1). This potential dose to the nearest offsite location is over 8,000 times lower than $0.1 \mathrm{mrem} / \mathrm{yr}$.

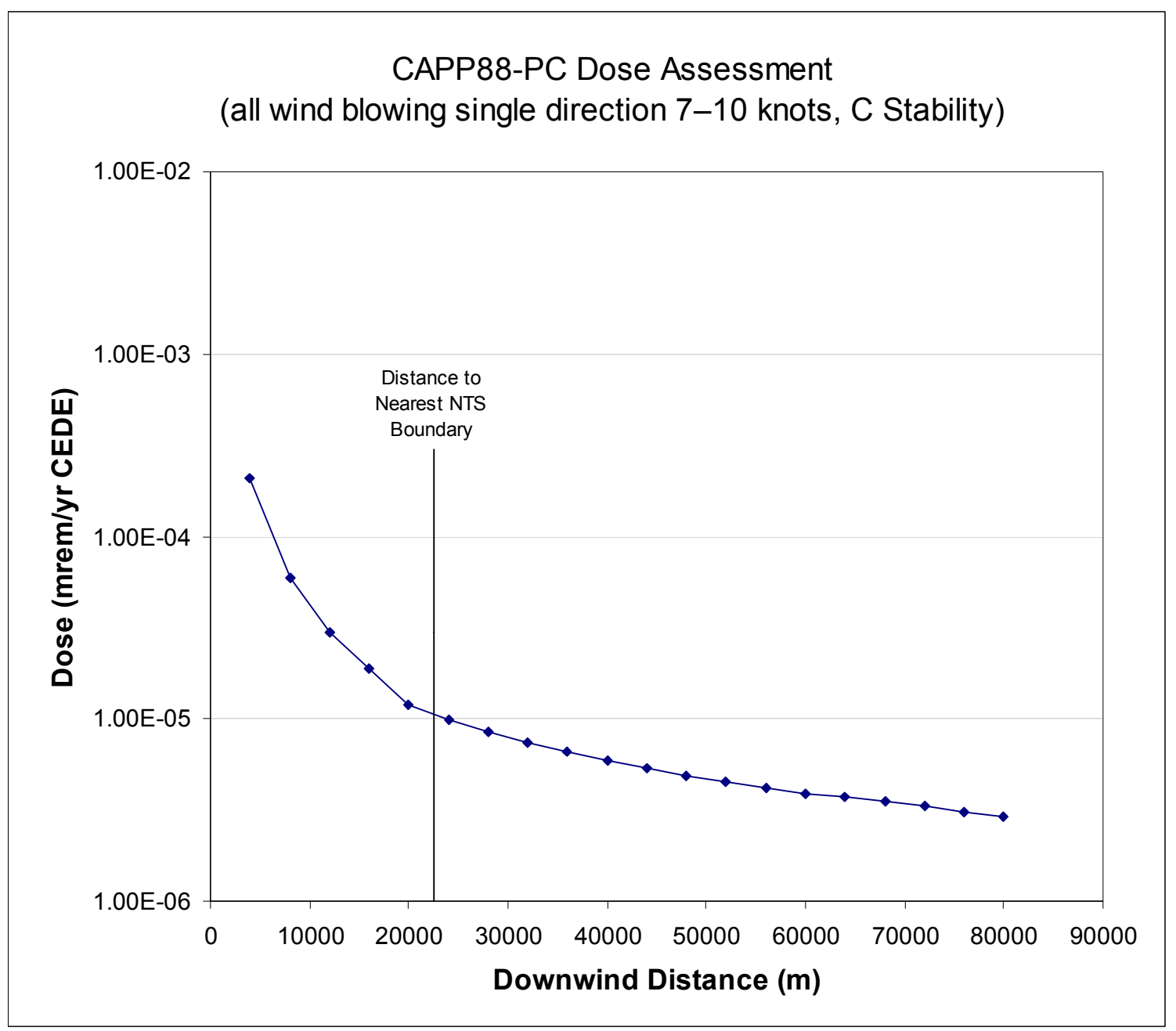

Figure F.1 Potential Dose from Research Project(s) in 2006

\section{CONSTRUCTION PROJECTS}

Planned activities of the Legacy Compliance Project consist of the construction of flood control structures in radiologically impacted portions of Area 8 on the NTS. The project plan is for grading, excavation, and construction of structures or berms to control runoff from the site. Because surface soils contain man-made radionuclides, an estimate of potential emissions to air was made. Based on project input, $578 \mathrm{yd}^{3}$ of soil were to be moved. At a soil density of $1.5 \mathrm{~g} / \mathrm{cm}^{3}$, this total was $6.63 \times 10^{8} \mathrm{~g}$. The radionuclide of primary concern was ${ }^{239} \mathrm{Pu}$, given its concentration and its contribution to potential dose being higher than other radionuclides present. Given the activity of ${ }^{239} \mathrm{Pu}$ in the area, the concentration of ${ }^{239} \mathrm{Pu}$ in the soil to be moved was estimated to be $67.8 \mathrm{pCi} / \mathrm{g}$. An EPA defined emission factor for soil removal and haulage (EPA, 2004) equal to $0.0128 \mathrm{~kg}$ of particulate matter emitted per $1 \times 10^{6} \mathrm{~g}$ of material handled was used, resulting in an estimated soil emission of $8.49 \mathrm{~kg}$. The ${ }^{239} \mathrm{Pu}$ emission was then 
$8490 \mathrm{~g} \times 67.8 \mathrm{pCi} / \mathrm{g}=5.76 \times 10^{5} \mathrm{pCi}$ or $0.576 \mu \mathrm{Ci}$. The potential dose from this release was determined by scaling to a previous CAP88-PC dose calculation of $5.1 \times 10^{-5} \mathrm{mrem} / \mathrm{yr}$ to the MEI from a $77 \mu \mathrm{Ci}^{239} \mathrm{Pu}$ emission, which resulted in an estimated dose of $4 \times 10^{-7} \mathrm{mrem} / \mathrm{yr}$ to a MEl at Amargosa Valley $67.5 \mathrm{~km} \mathrm{(42} \mathrm{mi)} \mathrm{south-southwest} \mathrm{of} \mathrm{the} \mathrm{project} \mathrm{site.} \mathrm{This} \mathrm{assessment} \mathrm{was}$ completed in 2006, but construction was not completed in 2006. 
This page intentionally left blank 


\section{APPENDIX G}

\section{IDENTIFICATION AND JUSTIFICATION FOR THE DEVELOPMENT OF METEOROLOGICAL DATA USED AS INPUT TO CLEAN AIR PACKAGE 1988 (CAP88-PC)}

\section{SITE CHARACTERISTICS}

The Nevada Test Site (NTS) is located in southern Nevada, approximately 105 kilometers (km) (65 miles [mi]) northwest of Las Vegas, Nevada, and encompasses an approximate rectangular area of 3,561 square kilometers $\left(\mathrm{km}^{2}\right)\left(1,375\right.$ square miles $\left.\left[\mathrm{mi}^{2}\right]\right)$. Topography is complex with generally north-south oriented ridges and valleys typical of Nevada. Terrain elevations range from almost 823 meters $(\mathrm{m})(2,700 \mathrm{feet}[\mathrm{ft}])$ in the extreme southwest corner of the NTS (Area 25) to almost 2,347 m (7,700 ft) on Rainier Mesa in the northern part of the NTS (Area 12).

In general, terrain slopes gently into broad valleys. In the few areas where steep canyons or cliffs exist, adequate wind and temperature data have been collected and analyzed to provide thorough documentation of the existence of typical up-slope and down-slope wind regimes as a function of time of day.

Meteorological support, observations, and climatological services for the NTS are provided to the U.S. Department of Energy, National Nuclear Security Administration Nevada Site Office (NNSA/NSO) by the Air Resources Laboratory, Special Operations and Research Division (ARL/SORD). The ARL/SORD is a National Oceanic and Atmospheric Administration (NOAA) office and supports NNSA/NSO programs under the authority of an Interagency Agreement between NOAA and NNSA/NSO.

An arid climate exists over the NTS. Annual precipitation ranges from 12.4 centimeters per year $(\mathrm{cm} / \mathrm{yr})(4.9 \mathrm{inches} / \mathrm{year}$ [in/yr]) at Station No. 5, to $16.8 \mathrm{~cm} / \mathrm{yr}(6.6 \mathrm{in} / \mathrm{yr})$ at Yucca Flat (Station No. 6), to $14.7 \mathrm{~cm} / \mathrm{yr}(5.8 \mathrm{in} / \mathrm{yr})$ at Desert Rock, to $32.5 \mathrm{~cm} / \mathrm{yr}(12.8 \mathrm{in} / \mathrm{yr})$ on Rainier Mesa (Station No. 12).

\section{METEOROLOGICAL OBSERVATIONS}

The ARL/SORD manages, operates, and maintains a meteorological monitoring program that is designed and used to support the NNSA/NSO authorized activities on the NTS. This vital program consists of many meteorological monitoring systems that have been brought together under the Meteorological Integrated Data Network (MIDNET). The MIDNET includes a Meteorological Data Acquisition (MEDA) network of approximately 30 mobile meteorological towers located primarily on the NTS (Figure G.1). MIDNET has been operated on the NTS for more than 40 years, has undergone several modernizations and upgrades, and serves as a solid basis for deriving climatological information.

The MIDNET consists of communications systems, local area networks, upper-air sounding stations, and surface-based instrumentation used to measure wind direction and speed, temperature, relative humidity, pressure, and precipitation. Routine and special surface observations are collected by trained ARL/SORD personnel 16 hour/day, Monday through Friday at the Desert Rock Meteorological Observatory (DRA; elevation 1,007 m [3,304 ft]) located $4.8 \mathrm{~km}$ (3 mi) southwest of Mercury, Nevada (Station No. 23) (Figure G.1). Upper-air observations (radiosondes) are taken twice daily from DRA. DRA has been in operation since May 1978. 


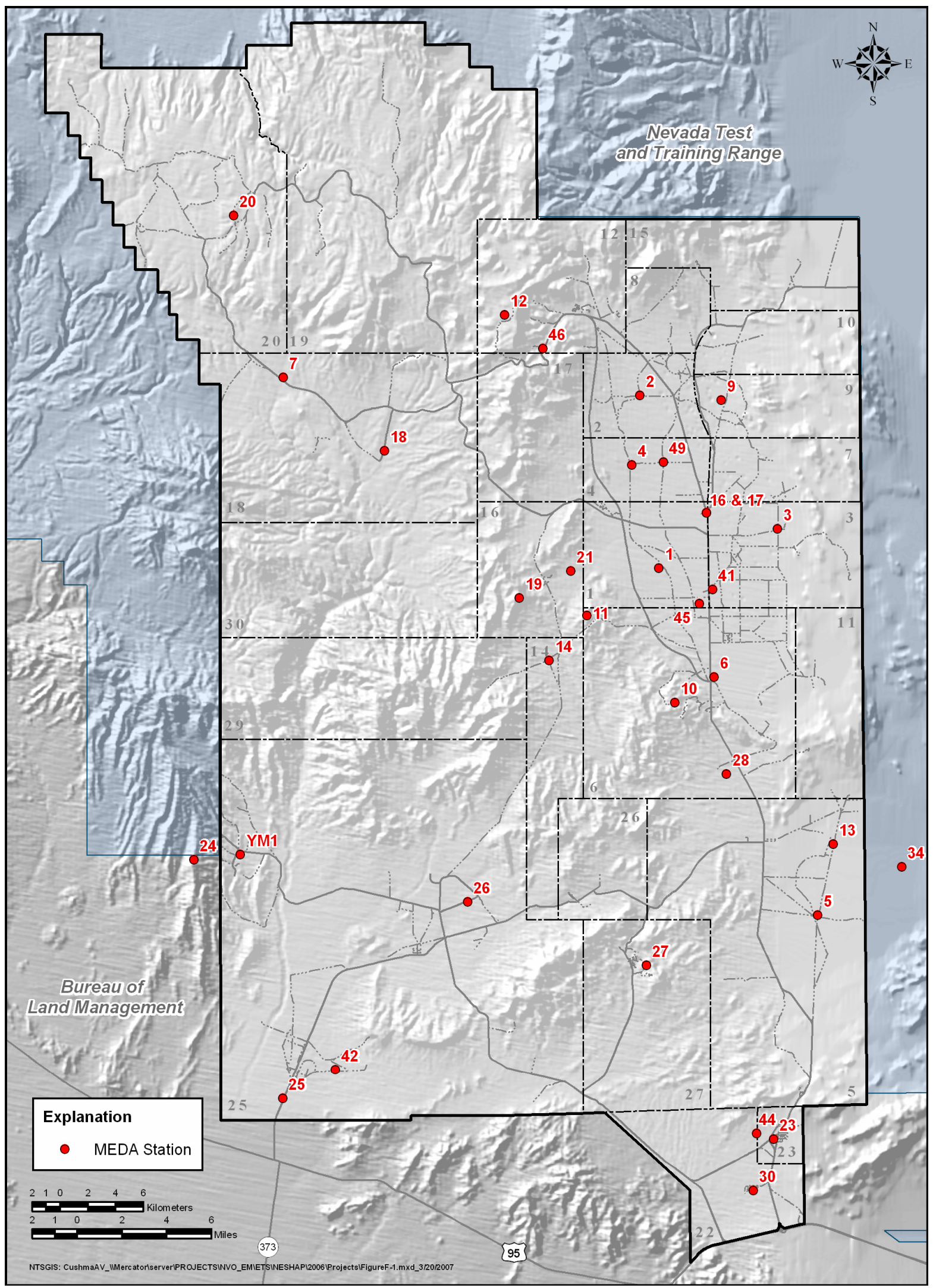

Figure G.1 Locations of MEDA Stations on the NTS in 2006 
DRA was built to replace a similar observatory that was located at the Yucca Flat Meteorological Observatory (UCC; elevation 3,924 ft, Station No. 6) from January 1962 through mid-May 1978. Consequently, surface and upper-air observations are also available from UCC for 1962-1978.

A key component of the MIDNET system is the MEDA. A MEDA station consists of an enclosed

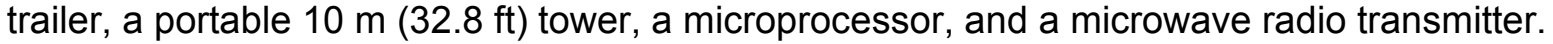
Wind speed and direction sensors are located on tower tops or booms oriented into the prevailing wind direction and at a minimum distance of two tower widths from the tower. Wind sensors are located $10 \mathrm{~m}$ above the ground.

Wind and temperature data have been collected on the NTS for more than 40 years. These and other meteorological data have been compiled into a comprehensive climatological database for the NTS. The MEDA data are especially useful in assessing boundary layer flow regimes on the NTS. MEDA station distribution and density (Figure G.1) are sufficient to document individual basin flow regimes and potential inter-basin air exchanges.

Ambient temperature and relative humidity sensors are located at $3 \mathrm{~m}(9.8 \mathrm{ft})$ above ground level. A total of 30 primary MEDA stations are located on or around the NTS (Figure G.1) to ensure that meteorological conditions are thoroughly documented for the complex terrain environment found on the NTS.

Wind direction is measured to two degrees of azimuth, and wind speed is accurate to 0.3 miles per hour (mph). Wind data are collected as 15 minute averages and are transmitted via microwave to a central processor every 15 minutes. These data are checked operationally by the duty forecaster, and quality control is assured by the ARL/SORD climatologist. Plotted wind products are generated every 15 minutes for operational use. The data are stored and archived for climatological purposes.

MEDA temperature is accurate to 0.36 degree Fahrenheit $\left({ }^{\circ} \mathrm{F}\right)$ between $-38^{\circ} \mathrm{F}$ and $140^{\circ} \mathrm{F}$ (absolute range for the NTS is $-20^{\circ} \mathrm{F}$ to $115^{\circ} \mathrm{F}$ ). Temperature measurements are instantaneous and are taken every 15 minutes at all MEDA stations. These data are also transmitted via microwave to a computer for processing, displaying, and archiving.

To utilize the most representative meteorological data available for NTS sources, cloud observations from DRA were melded with the concomitant MEDA winds from Mercury and Pahute Mesa. Similarly, the cloud observations from UCC were melded with MEDA wind data from Yucca and Frenchman Flats. The straight-line distance from DRA to Mercury is $4.8 \mathrm{~km}$ (3 mi); from UCC to Frenchman Flat is $19.3 \mathrm{~km}$ (12 mi); and from DRA to Pahute Mesa is $64.4 \mathrm{~km}(40 \mathrm{mi})$.

Cloud cover observations needed as input to the Stability Array (STAR) program are available from DRA (1978-present) and from UCC (1962-1978). Based on the available data, the cloud cover climatology from DRA and UCC are quite compatible. For example, UCC experiences 192 clear days annually, while DRA has 191 days. In addition, the average annual sky cover from sunrise to sunset for both stations is 3.9 tenths daily. The total number of cloudy days for UCC is 81 days and 82 days for DRA, annually. Therefore, the cloud cover observations from DRA and UCC can be considered as representative for most of the NTS. 


\section{APPLICATION TO CAP88-PC INPUT}

Based on the above considerations and on the limitations of the Clean Air Package 1988 computer program (CAP88-PC), the cloud cover data from DRA were considered to be representative of Pahute Mesa. Therefore, atmospheric soundings and cloud cover observations from DRA were melded with MEDA surface wind data from Pahute Mesa for input to the STAR program to provide the very best data for calculating transport and dispersion processes. For sources in Yucca Flat and Frenchman Flat, the cloud cover data from UCC were considered to be the most representative. Yucca Flat and Frenchman Flat are adjoining valleys of similar soil and vegetation types and similar meteorological and climatological conditions.

For sources at Mercury, the cloud observations from DRA are representative. DRA is only $4.8 \mathrm{~km}(3 \mathrm{mi})$ from Mercury.

The STAR file is a matrix that includes seven Pasquill stability categories (A through $G$ ), six wind speed categories, and 16 wind sectors from wind roses calculated for each specified MEDA station on the NTS. Beginning in 2002, only weather data for the current year were used in creating the STAR files for the CAP88-PC calculations. Calendar year 2006 data from the MEDA stations for the NTS areas were used by ARL/SORD personnel to prepare the following STAR files:

$\begin{array}{lr}\text { STAR File } & \text { NTS Area } \\ \text { meda09.str } & 10 \\ \text { meda13.str } & 5 \\ \text { meda17.str } & 3 \\ \text { meda20.str } & 20\end{array}$




\section{APPENDIX H}

\section{SUPPLEMENTAL INFORMATION}

\section{COLLECTIVE EFFECTIVE DOSE EQUIVALENT}

As discussed in Section III, the U.S. Environmental Protection Agency has approved the use of critical receptor monitoring locations on the Nevada Test Site (NTS) to demonstrate National Emission Standards for Hazardous Air Pollutants (NESHAP) compliance in lieu of using the Clean Air Package 1988 computer software (CAP88-PC) to calculate the radiation doses received by offsite residents within 80 kilometers $(\mathrm{km})(50$ miles [mi]) of the NTS emission sources. Since the U.S. Department of Energy (DOE) agreed that there is little benefit in doing CAP88-PC calculations just for the collective effective dose equivalent (DOE, 2004a), this calculation was not performed for calendar year 2006. As shown in Figure H.1, the collective effective dose equivalent (CEDE) has been consistently below 0.6 person-rem per year (/yr) (rem is roentgen equivalent man) for the years 1992 to 2004, indicating that it is unlikely that the CEDE will exceed 1 person-rem/yr. However, if operations at the NTS change whereby this is exceeded, this change will be reconsidered.

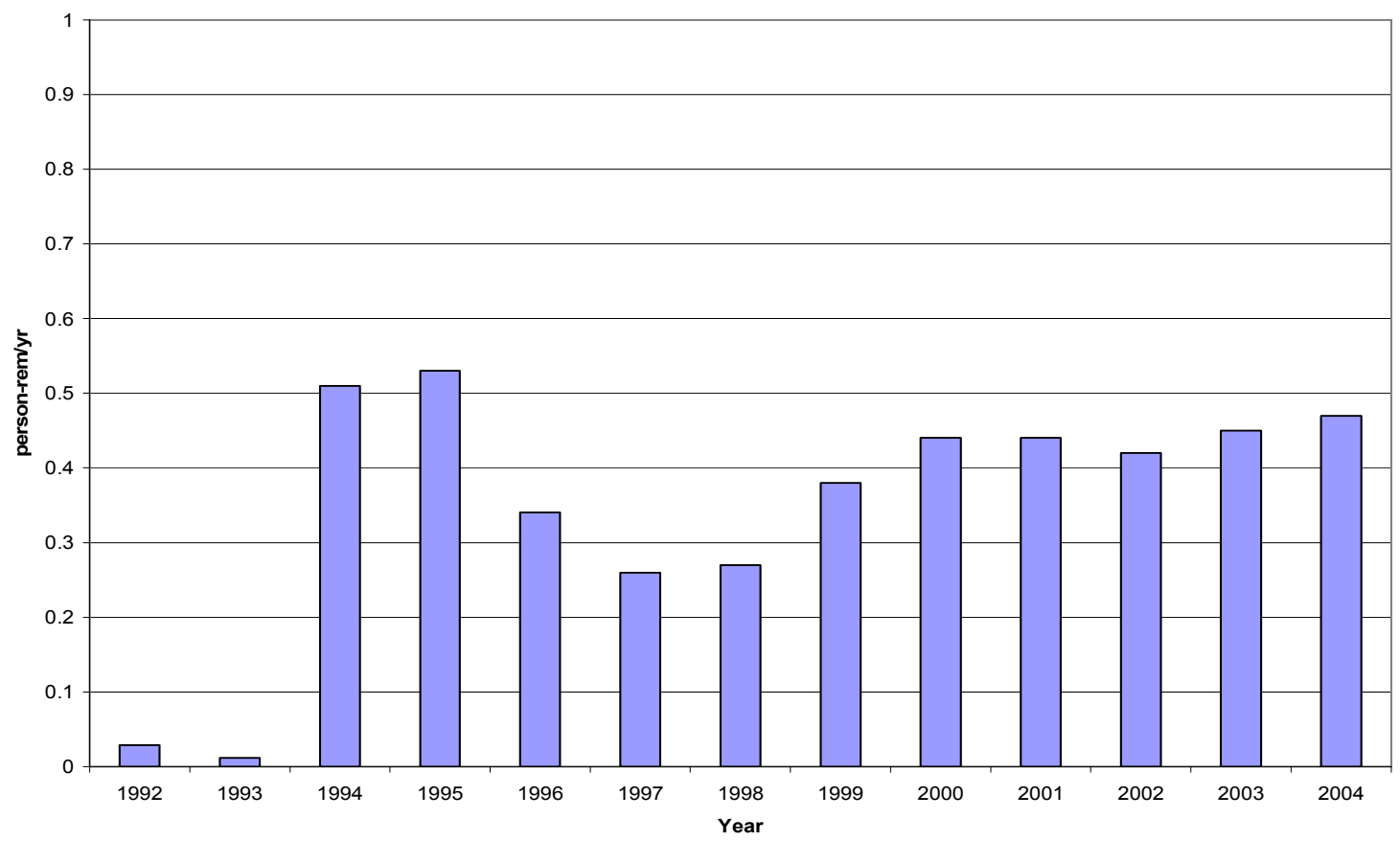

Figure H.1 CEDE to Populations within 80 km (50 mi) of Emission Sources 


\section{ESTIMATING TRITIUM EMISSIONS FROM SCHOONER AND SEDAN}

Prior to 2002, the areas of diffuse tritium emissions from the Sedan and Schooner sites were assumed to be the sizes of their craters. From the measurement of tritium in vegetation samples collected in 2002 and 2004 at these sites, the areas of emissions appeared to be much larger. Current estimates for these areas are $3.8 \times 10^{6}$ square meters $\left(\mathrm{m}^{2}\right)$ for Sedan and $3.6 \times 10^{6} \mathrm{~m}^{2}$ for Schooner. As this places the Schooner and Sedan air sampling locations within the source term area, the CAP88-PC concentration estimates at these sampler locations for a 1 curie per year $(\mathrm{Ci} / \mathrm{yr})$ release have high uncertainty (Figure $\mathrm{H} .2)$.

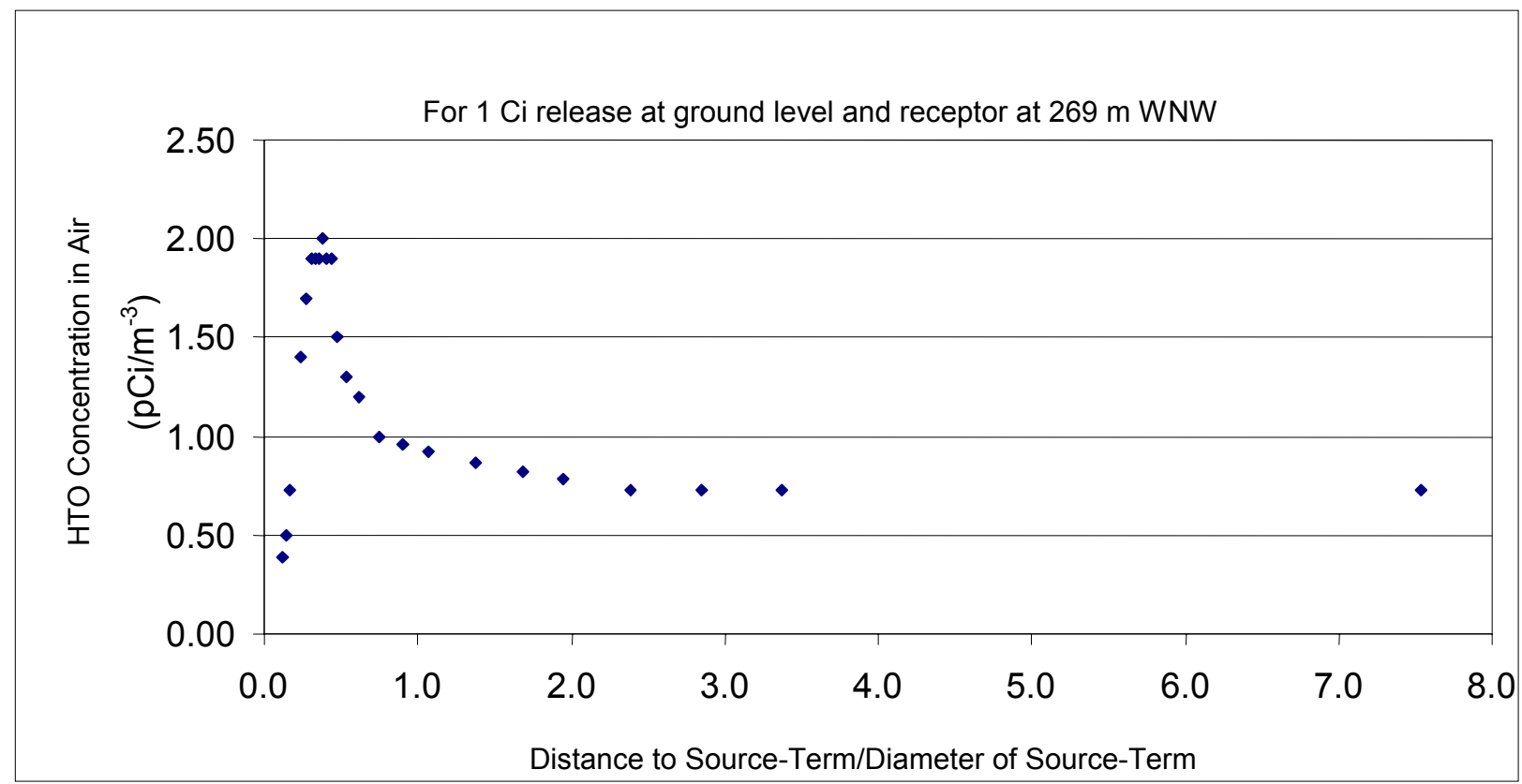

Figure H.2 CAP88-PC Predicted Air Concentration versus Ratio of Distance-to-Source/ Diameter of Source

According to CAP88-PC documentation, the software estimates for area sources is reliable only for locations where the ratio (distance between the sampling location and source) / (source diameter) is greater than about 1.3. At a ratio greater than 2.5 , the source is assumed to be a point source instead of an area source. To increase the reliability of tritium emission estimates, air samplers at further distances from the center of the source terms are included in making the release estimates, such as the air sampler positioned at Gate $20-2 \mathrm{P}$, which is $4,790 \mathrm{~m}$ southsoutheast of the Schooner crater. At this distance, area source is treated by CAP88-PC as a point source (ratio of 13). See Appendix D for a description of the method and results.

\section{COMPLIANCE WITH SUBPARTS Q AND T, Title 40 Code of Federal Regulations 61}

The NTS is regulated by Subpart $\mathrm{H}$ (National Emission Standards for Emissions of Radionuclides Other Than Radon from DOE Facilities), but not Q (National Emission Standards for Radon Emissions from DOE Facilities) or T (National Emission Standards for Radon Emissions from the Disposal of Uranium Mill Tailings). However, National Security Technologies, LLC (NSTec) includes Subpart Q in its Work Smart Standards. Therefore, radon 
flux measurements were made during this report period at the Area 3 and Area 5 Radioactive Waste Management Sites (RWMSs) to confirm inventory records that only trace amounts of radium were disposed of in these areas and to make sure that the radon fluxes are well below the standard of 20 pico-curies per square meter per second $\left(\mathrm{pCi} / \mathrm{m}^{2} / \mathrm{s}\right)$ required by Subpart $\mathrm{Q}$. The results of the most recent study (NSTec, 2007) showed that the airborne concentrations of radon and the flux measurements of radon were both at background levels. An assessment of the potential risks posed by the Area 5 RWMS to the public projected that the in-growth of radon-222 $\left({ }^{222} \mathrm{Rn}\right)$ from the decay of thorium-230 $\left({ }^{230} \mathrm{Th}\right)$ in thorium wastes would not exceed the standard for approximately 30,000 years (Shott et al.,1998).

\section{NON-DISPOSAL/NON-STORAGE SOURCES OF RADON EMISSIONS}

None of these sources exist on the NTS.

\section{QUALITY ASSURANCE PROGRAM FOR NESHAP COMPLIANCE}

The quality assurance program for samples collected and analyzed for NESHAP compliance is documented in an environmental monitoring plan (DOE, 2003). The applicable requirements of 40 CFR 61, Appendix B, Method 114, "Test Methods for Measuring Radionuclide Emissions from Stationary Sources" (EPA, 2001) and of DOE Order 414.1B, "Quality Assurance" (DOE, 2004b) have been implemented in this plan. 
This page intentionally left blank 


\section{DISTRIBUTION LIST}

DOE Headquarters

Les Pitts, NA-22, U. S. Department of Energy, 1000 Independence Avenue SW, Washington, D.C. 20585-1290

Office of Air, Water and Radiation Protection Policy and Guidance, EH-41 FORS, U.S.

Department of Energy, 1000 Independence Avenue SW, Washington, D.C. 20585-1290 (2)

Senior Advisor for Environment, Safety and Health, NA-1, U. S. Department of Energy, 1000 Independence Avenue SW, Washington, D.C. 20585-1290

\section{EPA}

Director, Air Division, Region 9, U.S. Environmental Protection Agency, 75 Hawthorne Street, San Francisco, CA 94103

Program Manager, Office of Radiation and Indoor Air, U.S. Environmental Protection Agency, 1200 Pennsylvania Avenue NW, Washington, D.C. 20460

\section{National Nuclear Security Administration, Nevada Site Office}

Assistant Manager for Environmental Management, U.S. Department of Energy, National Nuclear Security Administration, Nevada Site Office, P.O. Box 98518, Las Vegas, NV 89193 8518, M/S 505

Assistant Manager for National Security, U.S. Department of Energy, National Nuclear Security Administration, Nevada Site Office, P.O. Box 98518, Las Vegas, NV 89193 8518, M/S 505

Assistant Manager for Safety Programs, U.S. Department of Energy, National Nuclear Security Administration, Nevada Site Office, P.O. Box 98518, Las Vegas, NV 89193 8518, M/S 505

Deputy Assistant Manager for Environmental Management, U.S. Department of Energy, National Nuclear Security Administration, Nevada Site Office, P.O. Box 98518, Las Vegas, NV 89193 8518, M/S 505

Deputy Assistant Manager for National Security, U.S. Department of Energy, National Nuclear Security Administration, Nevada Site Office, P.O. Box 98518, Las Vegas, NV 891938518, M/S 505

Deputy Assistant Manager for Safety Programs, U.S. Department of Energy, National Nuclear Security Administration, Nevada Site Office, P.O. Box 98518, Las Vegas, NV 891938518 , M/S 505

Environmental Restoration Project, U.S. Department of Energy, National Nuclear Security Administration, Nevada Site Office, P.O. Box 98518, Las Vegas, NV 89193 8518, M/S 505

Team Lead, Environmental Protection Team, U.S. Department of Energy, National Nuclear Security Administration, Nevada Site Office, P.O. Box 98518, Las Vegas, NV 891938518 , M/S 505 (3)

U.S. Department of Energy, National Nuclear Security Administration, Nevada Site Office Technical Library, P.O. Box 98518, M/S 505, Las Vegas, NV 89193-8518 (1-CD) 
U.S. Department of Energy, National Nuclear Security Administration, Nevada Site Office, Public Reading Facility, c/o Nuclear Testing Archive, P.O. Box 98521, M/S 400, Las Vegas, NV 89193-8521 (1-CD)

Waste Management Project, U.S. Department of Energy, National Nuclear Security Administration, Nevada Site Office, P.O. Box 98518, Las Vegas, NV 89193 8518, MS505(3)

\section{State of Nevada}

Bureau Chief, Bureau of Health Protection Services, 1179 Fairview Drive, Suite 201, Carson City, NV 89701-5405

Bureau Chief, Nevada Division of Environmental Protection, Bureau of Air Pollution Control, 901 South Stewart St. Suite 4001, Carson City, NV 89701-5249

Nevada Division of Environmental Protection, Bureau of Federal Facilities, 2030 East Flamingo Road, Suite 230, Las Vegas, NV 89119-0818

\section{Other}

Assistant Manager for ES\&H, Office of Repository Development, 1551 Hillshire Drive, Las Vegas, NV 89134

Chief, Environmental Management Flight B625, 99th CES/CEV, 4349 Duffer Drive, Suite 1601, Nellis AFB, NV 89191-7007

Director, Center for Environmental Remediation and Monitoring, Desert Research Institute, $755 \mathrm{E}$. Flamingo Road, Las Vegas, NV 89119

Director, Death Valley National Park, P.O. Box 579, Death Valley, CA 92328

State Director, Bureau of Land Management, P.O. Box 12000, Reno, NV 89520-0006

Supervisor, Southern Nevada Field Office, U.S. Fish and Wildlife Service, 4701 North Torrey Pines Drive, Las Vegas, NV 89130

U.S. Department of Energy, Office of Scientific and Technical Information, P.O. Box 62, Oak Ridge, TN 37831-0062 (1 - electronic) 